\title{
The Constitutionality of Expanding Prepublication Review of Government Employees' Speech
}

The conflict between the secrecy necessary to ensure national security and the free speech guarantees of the first amendment is an unavoidable one. ${ }^{1}$ Perhaps nowhere is this conflict better illustrated than in the Reagan administration's existing and proposed programs to subject government employees to lifelong prepublication review-programs to screen in advance books, articles, speeches or other normally protected utterances to ensure that material for public consumption does not contain clàssified information. ${ }^{2}$ The problem is not trivial.

1. This truism has been recognized by our leaders since the earliest days of the Republic. As James Madison stated, "the purest of liuman blessings must have a portion of alloy in them." THE FeDeralist No. 41, at 255 (J. Madison) (C. Rossiter ed. 1961). As a result, grants of power to the government must be made with a recognition that the power may be abuscd. 1 n analyzing such grants of power, Madison said the people must first decide "whether such a power be necessary to the public good"; and, if it is, how "to guard as effectually as possible against a perversion of the power to the public detriment." Id. at 256.

2. Prepublication review has been an established practice for years in certam highly sensitive government agencies such as the Central Intelligence Agency (CIA) and the National Security Ageney (NSA). In 1981, the Reagan administration apparently broadened the categories of employees to whom a lifelong censorship requirement applied. The action was taken, without the knowledge or consent of Congress, under a new interpretation of an existing presidential order. More than 119,000 government employees in 33 agencies, not counting the ClA and NSA, with access to highly sensitive classified information, are subject to the current requirement. The cxisting prepublication review program came to light during a congressional investigation into a Reagan proposal to broaden further the category of materials an employee might write or say that would be subject to prepublication review by government censors. Thousands of government contractor employees have also signed nondisclosure agreements that provide for lifelong censorship. See Gen. Acct. Off. Rep. NSIAD-84-135, Polygraph and Prepublication Review Policies of FEDERAl AGENCIES at Enclosure II (1984) [heremafter cited as GAO Report] (on file with the California Law Review); The Secret Life of NSDD 84, Colum. Journalism Rev., July/Aug. 1984, at 22-23; Burnham, Censorship Accords Signed by Thousands, Study Shows, N.Y. Times, June 14, 1984, at B28, col. I.

Twelve government agencies require prepublication review of all employees' speech regardless of whether they have access to classified information. Besides the Department of Defense and the State Department, the Department of Education, the Peace Corps, the Tennessee Valley Authority, and the Federal Reserve are among the dozen agencies enforcing such review programs. These review requirements result from each agency's internal pohcies and apply only for the duration of employment, rather than for life. The scope of the review programs varies widely from agency to agency. GAO REPORT, supra, at 3; $i d$. at Enclosure III. The government spent more than 5200 working days reviewing materials subınitted by employees in 1983. Id. at Enclosure I, p. 6.

The analysis in this Comment, while applicable generally to all prepublication review pro- 
The release of certain information, even in time of peace, would not only be costly, but could also seriously impair alliances with friendly nations, or imperil intelligence methods and vital sources of intelligence information. ${ }^{3}$ At time of war, the stakes may be even higher. ${ }^{4}$

On the other hand, overzealous government censors could effectively stifle the flow of important information about the governmentinformation that exactly fits the "free trade in ideas"s and protection of democracy $^{6}$ notions that have stood as the cornerstones of the first amendment. ${ }^{7}$ Thus prepublication review could be seen as both a tool to promote free speech by ensuring the continued existence of a society that values free speech, and as a club to restrict expression and promote tyraimy. The key is to ensure that in balancing the coinpeting interests, hiberty is adequately protected. As Janes Madison observed, if the remedy destroys hiberty, the "remedy . . . was worse than the disease."8

This Comment exammes a recent Reagan administration proposal to subject all government and government contractor employees with

grams, is directed primarily at the Reagan administration's latest attempt to broaden the scope of prepublication review.

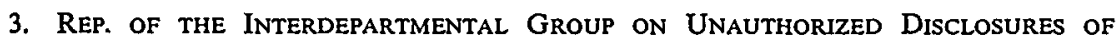
Classified INFormation, at B2 (I982) [hereinafter cited as INTERDEPARTMENTAL GroUP REPORT] (on file with the California Law Review).

4. For example, during World War II many lives were lost in the November 14, 1940 bombing of Coventry, England even though the British knew of the planned attack. British Intelligence had developed a secret decoding machine, known as the Uitrasecret or Ultra, that was able to break an allegedly unbreakable German code. When he learned of the planned attack on Coventry, however, Sir Winston Churchill decided not to advise the local authorities to evacuate the town because to do so would alert the Germans to the existence of the decoding device. See generally R. Lewin, Ultra Goes to WAR 99-103 (I978); F. WinterbothaM, THE ULTRA SECRET 60-61 (1974).

5. The inarketplace of ideas theory of the first amendinent derives from Justice Holmes' opinion in Abrams v. United States, 250 U.S. 616, 630 (1919) (Holmes, J., dissenting). Under Holmes' approach, by perinitting the free interplay of ideas, competition in the idea marketplace will bring people to an understanding of the truth. See M. Shapiro, Freedom of Spezch: The Supreme Court AND Judicial Review 51-54 (1966). The "truth" Holmes refers to is generally agreed to be political truth and is related to the first aniendment protection of democracy theory.

6. See Whitney v. Cahifornia, 274 U.S. 357, 372 (1927) (Brandeis, J., concurring); see generally A. Meikeluohn, Free Speech AND its Relation to SElF-Government (1948).

7. Other purposes for free speech have been articulated. Justice Brandeis, concurring in Whitney v. California, 274 U.S. 357, 372 (1927) (Brandeis, J., concurring), argued cogently that the freedoin to speak is an end in itself; thus, a broadened category of protected speech beyond that required to ensure the continued survival of the nation is appropriate. Id. at 375. Brandeis also saw speech as a safety valve for society, helping to maintain a inore stable society. Id. at 37576. On the purposes of the first amendinent, see generally T. EMERSON, THE SYSTEM OF FrEEDOM OF EXPRESSION 6-9 (1970).

Of course agreement on the purposes of speech protection does not imply agreenient on the scope of that protection. See, e.g., Bork, Neutral Principles and Some First Amendment Problems, 47 IND. LJJ. 1 (1971) (accepting the various asserted benefits of the first amendment but arguing that only the discovery and spread of poitical truth has a constitutional dimension deserving judicial, as opposed to legislative, protection).

8. The Federalist No. 10, at 78 (J. Madison) (C. Rossiter ed. 1961). 
access to certain types of classified information to a lifelong prepublication review requirement. ${ }^{9}$ Part I examines the antecedents to the review proposal as well as specific provisions of the proposal itself. Part II tests the concept of prepublication review against Supreme Court inandates on prior restraint, overbreadth and vagueness, and conditions on government einployment. The Comment then considers prepublication review in light of several cases upholding sucl prograins as impleinented by the CIA. ${ }^{10}$ After concluding that the new proposal probably includes some constitutional defects under these doctrines, Part III examines alternatives available to the government that would more effectively protect government secrets without running afoul of the first amendment. The Cornment concludes that, althougli a system of prepublication review is ill advised because of repugnance to the policies that underlie the first amendment, uncertainty in the case law makes it impossible to forecast low the Supreme Court would react to a vastly broader review scheme than the one it uplield in Snepp $v$. United States. ${ }^{11}$ Tlierefore, the Comment suggests that Congress should clarify the matter itself by passing legislation that expressly forbids prepublication review of government einployees' speecl.

I

\section{The Evolution of Prepublication Review Under the REAGAN ADMINISTRATION}

The United States has, from its earliest history, recognized the important role the national government plays in protecting the country from foreign peril. ${ }^{12}$ Within this sclieme of federal supremacy, the executive brancli las long been viewed as predominant, witli the President liaving broad, though not unlimited, powers over matters of foreign affairs and military policy. ${ }^{13}$ Since 1911 , the nation has specifi-

9. For specifics on the proposed review program, see infra notes 41-58 and accompanying text. Though that specific proposal has been suspended under pressure from Congress, see Werner, Aide Says Reagan Shifts on Secrecy, N.Y. Times, Feb. 15, 1984, at A1, col. 1, the issue is not a dead letter. The legahty of such programs remains important because thousands of government employees are already subject to prepublication review. See supra note 2. Moreover, it appears likely that President Reagan will revive the proposal if he is reelected, albeit possibly in somewhat altered form. Taylor, Secrecy Proposal: Risks Weighed Against Gains, N.Y. Tines, Feb. 20, 1984, at A13, col. 1 (stressing that the program was not revoked but only suspended pending discussions with Congress); Werner, supra, at A20, col. 4. Prepublication clearance is also the subject of proposed legislation. H.R. 4681, 98th Cong., 2d Sess. (1984). For the sake of clarity, this Comment examines the suspended Reagan administration program for illustrative purposes.

10. See, e.g., Snepp v. United States, 444 U.S. 507 (1980) (per curiam).

11. 444 U.S. 507 (1980) (per curiam).

12. In 1787, James Madison said, "Security agamst foreign danger . . . is an avowed and essential object of the American Union." THE FEDERALIST No. 41, at 256 (J. Madison) (C. Rossiter ed. 1961).

13. See, e.g., Chicago \& S. Air Limes v. Waterman S.S. Corp., 333 U.S. 103, 111 (1948) 
cally protected military secrets and punished espionage. ${ }^{14}$ And for more than three decades, the President has had the delegated power to establish a system of classified information. ${ }^{\text {is }}$

\section{A. The Problem of Leaks}

\section{The Interdepartmental Group Report}

Despite extensive classification systems and laws imposing touglı criminal penalties for release of classified information, unauthorized disclosures of classified information are perceived as a continuing problem by officials in the Reagan administration. Indeed, officials have stated that disclosures are becoming more frequent and inore serious.

This concern over leaks led the President to order a special interagency task force, headed by then Deputy Assistant Attorney General Richard $\mathrm{K}$. Willard, to formulate recommendations on how to curb

(President, with access to intelligence information, uniquely qualified to make decisions and take action in the foreign affairs and military areas); United States v. Curtiss-Wright Export Corp., 299 U.S. 304 (1936). But see Youngstown Sheet \& Tube Co. v. Sawyer, 343 U.S. 579 (1952) (President's powers not unlinited); see also Haig v. Agee, 453 U.S. 280, 289 n.17 (1981) (President's extensive power in foreign relations area "like every other governmental power, must be exercised in subordimation to the applicable provisions of the Constitution' ") (quoting United States v. Curtiss-Wright Export Corp., 299 U.S. 304, 320 (1936)).

14. In 1911, Congress passed the Defense Secrets Act of 1911, cl. 226, 36 Stat. 1084, 1084-85 (1911), which provided for fines and/or miprisonment for acquiring or communicating national defense information without authorization. Subsequently, Congress passed the Espionage Act of 1917, 18 U.S.C. $\$ \S 793,794,798$ (1982), expanding potential criminal liability for the intentional breach of national secrets and providing for liarsli penalties. Even before the Defense Secrets Act, the federal government pumished treason, unlawful entry into military bases, and theft of government property. For a detailed discussion of the espionage statutes and their history, see Edgar \& Schmidt, The Espionage Statutes and Publication of Defense Information, 73 Colum. L. REv. 929, $936-42$ (1973).

15. National Security Act of 1947,50 U.S.C. $\S 401$ (1976 \& Supp. V 1981). Specifics of the classification system are prescribed by executive order, with the current rules in Exec. Order No. 12,356, 3 C.F.R. 166 (1983), reprinted in 50 U.S.C.A. $\$ 401$ n. $\dagger$ (West Supp. 1984), revoking and superseding Exec. Order No. 12,065, 3 C.F.R. 190 (1979), reprinted in 50 U.S.C. $\S 401$ n. $\dagger$ (Supp. V 1981). President Reagan's classification scheme altered President Carter's by changing the presumptions when doubts arise about whether to classify material and if to classify, at what level. Contrary to the Carter approach, the Reagan order resolves doubts in favor of classifying and doing so at a higher level. Exec. Order 12,356, § 1.1(c), 3 C.F.R. 167 (1983), reprinted in 50 U.S.C.A. $\S 401$ n.† (West Supp. 1984). The Reagan classification scheme, however, retains the fainiliar three-tier classification hierarcliy-"confidential," "secret," and "top secret"-as well as the requirement that "[i]nformation nay not be classified ... unless its disclosure reasonably could be expected to cause damage to the national security."

Recently, Professor Cheh explored the abuses that niay result froin essentially unchecked executive power to withhold information from the public. She advocates a nore active judicial role in scrutinizing executive actions in the secrecy area, in part through recognition of first amendment rights for government employees that are coextensive with those enjoyed by the general population. See Cheh, Judicial Supervision of Executive Secrecy: Rethinking Freedom of Expression for Governmcnt Employees and the Public Right of Access to Government Information, 69 Cornell L. Rev. 690 (1984). 
these disclosures. ${ }^{16}$ The Interdepartmental Group Report, issued March 31, 1982, stated that the unauthorized publication of classified information is "a routme daily occurrence." 17 The report authors worried that the frequency of leaks and the rarity of disciplinary action for employees leaking imformation may lead other government officials to beheve there is nothing wrong with leaking classified information. ${ }^{18}$

16. The task force did not examine disclosures that result from foreign espionage activitics. Rather, it focused only on anonymous leaks to the media and disclosures made in publications by former officials. INTERDEPARTMENTAL GROUP REPORT, supra note 3, at B2.

17. Id. at B1. The statement was not further quantified or supported. Similar statements about the frequency of disclosures appear throughout the report as well as in testimony by Group Chairman Richard K. Willard before two congressional hearings in 1983. See National Security Decision Directive 84: Hearing Before the Senate Comm. on Governmental Affairs, 98th Cong., 1st Sess. 9, 24 (1984) (testimony and statement of Richard K. Willard, Deputy Assistant Attorney General) [heremafter cited as Senate NSDD-84 Hearings]; Presidential Directive on Safeguarding National Security Information and Polygraph Examinations of Federal Employees: Hearings Before the Subcomm on Legislation and National Security of the House Comm. on Government Operations, 98th Cong., 1st Sess. (forthcoming) (statement of Richard K. Willard, Deputy Assistant Altorney General) [hereinafter cited as House NSDD-84 Hearings] (on file with the California Law Review).

Willard's testimony before the House illustrates the conundrum that arises when citizens attempt to evaluate the scope of the disclosure problem. Though Willard asserted that damaging disclosures appear "regularly and frequently" in the media, he stated that "[e]xamplcs of the harm caused by such disclosures are themselves classified and cannot be provided in a public hearing." House NSDD-84 Hearings, supra. In response to an inquiry from the Senate Committee, the Defense Department provided a brief description of 40 unauthorized disclosures over the last decade. Senate NSDD-84 Hearings, supra, at 106-11 (written response to committee inquiry by Ret. Gen. Richard G. Stilwell, Deputy Undersecretary of Defense). There is no indication how many of these were the result of inadvertent rather than intentional acts. It is also unclear how many involved the type of information that would be covered by the proposed nondisclosure agrcement.

Attempts to quantify the disclosure problem are not entirely conclusive. Testimony by the General Accounting Office before the House Subcommittee on Legislation and National Sccurity indicated that the number of serious disclosures is quite low. HOUSE COMM. ON GoverNMENT Operations, The Administration's Initlatives to Expand Polygraph Use and lmpose Lifelong Censorship on Thousands of Government Employees, H.R. Rep. No. 98-578, 98th Cong., Ist Sess. 15 (1983) [heremafter cited as House NSDD-84 REPORT]. The GAO reported that in the last five years there were 21 unauthorized disclosures made in writings or speeches of current or former employees, of which two would have been covered by the proposed review program. Id.; accord House NSDD-84 Hearings, supra (statcunent of Rep. Mel Levine, Member of Congress). The GAO report to Congress last June indicated that of 51 agencies that handle classified information, four reported a total of 43 unauthorized disclosures during 1983. Of these, only nine were reported to the Department of Justice. GAO REPORT, supra note 2, at Enclosure I, p. 6.

The CIA's experience with prepubhication review, however, indicates that disclosures may be more widespread. The CIA Publications Review Board, which has administered that agency's prepublication screening prograin simce 1977, had reviewed 929 manuscripts as of early September 1983. Of these, 225 were approved only after required changes were made, though most of the changes were "quite minor." Another 16 manuscripts were disapproved when found to contain "so inuch classified information that, when the information was deleted, the remaiming material was imcomprehensible and could not be rewritten in an intelligible manner." Senate NSDD.84 Hearings, supra, at 141 (written response to cominittee inquiry by Ernest Mayerfeld, Deputy Director, CIA).

18. INTERDEPARTMENTAL GRoup RePORT, supra note 3, at B2-B3. The report acknowledged that this perception is encouraged by an apparent double standard for dcaling with disclo- 
New policies are necessary, the report stated, to emphasize to employees the seriousness of protecting secrecy.

\section{a. The Harm Caused by Leaks}

In fact, the report listed four specific harms that result from unauthorized disclosures. First, inedia reports containing classified information give America's adversaries valuable intelligence concerning defense and diplomatic strategies and capabilities. Second, disclosures can lead to "vetos by leak," situations in which, by leaking certain information, a bureaucrat can block proposed government actions, interfering with the government's ability to function democratically and efficiently. Third, leaks can endanger intelligence programs by causing sources to "dry up," by endangering the lives of agents, and by exposing equipment to "countermeasures." Finally, foreign governments are less willing to cooperate with the United States when it is unable to protect confidential information and relationships. ${ }^{19}$

\section{b. The Inadequacy of Criminal Punishment}

Unauthorized disclosures of classified information generally represent violations of one or inore criminal provisions of the United States Code. ${ }^{20}$ Thus, the serious sanctions provided in tlose statutes sliould deter unauthorized disclosures. However, according to tlie Interdepartinental Group, even when a suspect is identified, criminal prosecution can itself harm national security. ${ }^{21}$ Prosecution tends to confirm the accuracy and sensitivity of the information disclosed, so agencies often prefer not to prosecute in order to inamtam doubt about the accuracy of a disclosure. In addition, in order to convict, the governinent must prove damage to national security, and this may require additional disclosures. These probleins are compounded by the requirement that trials be open to the public and tried to a jury. ${ }^{22}$ Whetler for these or for

sures by high-ranking officials, under which "friendly" leaks of classified information are often overlooked. Id. at B4. Indeed, one recent account called intentional leaks of secret information to the press "a way of life" in the Reagan administration, where the President's closest aides, described as "consummate professionals" in public relations, use the leaks for purely political manipulation. A. HalG, CAVEAT 17 (1984).

19. INTERDEPARTMENTAL GROUP REPORT, supra note 3, at B1-B2. Though one could dispute the validity and severity of some of the harms asserted by the Group, these harms are assumed to be valid for present purposes.

20. E.g., Espionage Act of 1917, 18 U.S.C. $\$ \S 793,794,798$ (1982); Atomic Energy Act of 1954, 42 U.S.C. $\$ 2277$ (1982); Intelligence Ideutities Protection Act of 1982, 50 U.S.C.A. $§ 421$ (West Supp. 1984). The constitutionality of the Intelligence Identities Protection Act las been questioned. See Note, The Constitutionality of the Intelligence Identities Protection Act, 83 CoLuM. L. REV. 727 (1983).

21. INTERDEPARTMENTAL Group REPORT, supra note 3, at C7-C9.

22. Id. at C8. But see Classified Information Procedures Act of 1980, 18 U.S.C. app. $\$ \S 4,9$, $11,12,15-17,20,32$ (1982) (providing special procedures in cases involving information crucial to 
other reasons, the Justice Department has never successfully prosecuted a case mvolving a inere unauthorized disclosure. ${ }^{23}$ Therefore, the Interdepartmental Group deemed programs outside the criminal justice system necessary to deal with the problem.

\section{c. Recommendations of the Interdepartmental Group}

To curb the disclosures, the Group recommended expanded use of prepublication review programs, ${ }^{24}$ enactınent of a criminal provision specifically prohibitimg willful unauthorized disclosure of classified information, ${ }^{25}$ stricter adherence to existing security program provisions that at the time were "frequently ignored," 26 and better investigation of and sanctions for leaks, ${ }^{27}$ including expanded use of polygraphs as an investigative aid. ${ }^{28}$ The report also recommended revismg rules concerning contact between media representatives and government officials to require advance approval of meetings by superiors and better recordkeeping of such contacts. ${ }^{29}$

\section{National Security Decision Directive 84}

Almost a year later, President Reagan, adopting most of the Interdepartmental Group's recommendations, issued a directive on safeguarding national security information. Known as National Security Decision Directive 84 (NSDD-84), ${ }^{30}$ the directive found "unlawful dis-

national security, mcluding greater use of protective orders, in camera proceedings, and sealed records). The inability to block disclosures through the use of criminal sanctions is an interesting paradox that parallels the difficulty of assessing the magnitude of the disclosure problein. See supra note 17.

23. Fact Sheet on Presidential Directive on Safeguarding National Security Information, Department of Justice, Mar. 11, 1983, at 2, reprinted in Senate NSDD.84 Hearings, supra note 17, at $88-90$ [hereinafter cited as Fact Sheet].

24. INTERDEPARTMENTAL GROUP REPORT, supra note 3, at CI2-CI3.

25. Id. at $\mathrm{C} 14$. The proposed statute would overlap significantly with existing provisions barring disclosure of certain types of information, but the Group recommended this additional code section "to close the gaps in the present law." Id.; see also infra notes 307-08 \& 313-14 and accompanying text.

26. INTERDEPARTMENTAL GROUP REPORT, supra note 3, at D1. Among the "obvious" principles often ignored, the report included careful screening of persons receiving security clearances, proper identification and storage of classified material, and limiting access to classified information to persons who have both the proper clearances and a "need to know." Id.

27. Id. at F1-F2.

28. Id. at F4-F5. The report specifically cautioned that polygraphs should be used selectively with results considered "within the context of a complete investigation. The polygraph should not be used for dragnet-type screening of a large nuinber of suspects or as a substitute for logical investigation by conventional means." Id; $c f$. infra note 35.

29. INTERDEPARTMENTAL GROUP REPORT, supra note 3, at D3-D4.

30. The directive [hereinafter cited as NSDD-84], issued Mar. 11, 1983, is reprinted in Senate NSDD-84 Hearings, supra note 17, at 85-86 and in 9 MEDIA L. REP. (BNA) 1759-60 (1983). 
closures of properly classified information"31 a "matter of grave concern."32 Among other things, it ordered each agency that handles classified information to require nondisclosure agreements from all employees $^{33}$ with access to Sensitive Compartmented Information (SCI), ${ }^{34}$ and the agreement "must include a provision for prepublication review to assure deletion of SCI and other classified information." 35 The order was not expected to eliminate all unlawful disclosures. Rather, it was an attempt by the administration to reduce the frequency and seriousness of disclosures through stricter policy enforcement and to emphasize to employees the duty they have to protect the confidentiality of classified information. ${ }^{36}$ The directive attempts to stop leaks before they occur, simce policing disclosure through subsequent criminal punishment is inadequate.

The various provisions of NSDD-84, if fully implemented, would affect approximately 2.5 million government and 1.5 million contractor employees. ${ }^{37}$ The prepublication review proposal, applicable only to

31. For a discussion of whether the government's classification procedures are subject to judicial review, see infra notes $152-60$ and accompanying text.

32. NSDD-84, supra note 30, at introduction.

33. For purposes of the prepublication review program, the term "employee" means current and former employees of both the government and government contractors.

34. SCI is information that "involves or derives from intelligence sources or methods and is classified or classifiable under the standards of Executive Order 12,356 or under other Executive Orders or statutes." SCI Nondisclosure Agreement, at If 1, reprinted in House NSDD-84 Hearings, supra note 17 (exhibit C to statement by Richard K. Willard, Deputy Assistaut Attorney General). Beyond this, no specific definition of SCI appears to exist. In testimony before a Senate committee, however, former CIA Director Williaun Colby described SCI as "a very narrow category of very highly sensitive kinds of information" that is carefully documented, controlied, and moved into another category as it becomes less sensitive. Senate NSDD-84 Hearings, supra note 17, at 37.

35. NSDD-84, supra note 30 , at $\{1$ (b). The directive also required nondisclosure agreements from all persons with access to classified information. This agreement, as promulgated by the Justice Department's Information Security Oversight Office, does not include a provision mandatimg prepublication review. 48 Fed. Reg. 40,849 (1983) (to be codified at 32 C.F.R. $\S 2003$ ). It does, however, provide for civil penalties for disclosure without authorization, whicl can be read as a de facto prepublication review requirement.

In addition, NSDD-84 ordered creation of internal procedures for investigation and reporting of unauthorized disclosures and mandatory sanctions against employees who are found to have violated disclosure rules or who refuse to cooperate with an investigation. NSDD-84, supra note 30 , at $\llbracket 2$. The FBI is also authorized to investigate leaks. Id. at $\llbracket 3$. Policies restricting employee contact with media representatives were also ordered. Id. at If 1 (d). Finally, among the most controversial provisions, the directive ordered revision of policies on polygraph use to permit expanded use of the machine as an investigative tool. Under the provisions, einployees could be required to submit to polygraphs with automatic "adverse consequences" to follow an employee's refusal to submit. Id. at I 5; cf. supra note 28. See also Fact Sheet, supra note 23; Pear, President Orders Curbs in Handling of Classified Data, N.Y. Times, Mar. 12, 1983, at 1, col. 4; Thornton, President Moves to Plug Leaks, Washington Post, Mar. 12, 1983, at 1, col. 1.

36. Fact Sheet, supra note 23, at 3.

37. House NSDD-84 Hearings, supra note 17 (statement of Kenneth J. Coffey, Associate Director, U.S. General Accounting Office). 
persons with SCI access, would affect 128,000 individuals. ${ }^{38}$ A standard SCI Nondisclosure Agreement mandated by NSDD-84 was released $^{39}$ by the Justice Department, along with implementimg regulations, ${ }^{40}$ on August 25, $1983 .{ }^{41}$

\section{B. The SCI Nondisclosure Agreement}

\section{Terms of the Nondisclosure Agreement}

Though prepublieation review is not an entirely new aspect of government security programs, the Reagan program is broader than any program previously used.

\section{a. General}

The proposed agreement requires any person with SCI access to submit for security review

all inaterials, including works of fiction ... . which contain or purport to contain:

(a) any $\mathrm{SCI}$, any description of activities that produce or relate to $\mathrm{SCI}$, or any information derived froin $\mathrm{SCI}$;

(b) any classified information from intelligence reports or estiinates; or

(c) any information concerning intelligence activities, sources or methods. ${ }^{42}$

The proposed agreement speaks of the review requirement as consideration for being granted a position of "special confidence and trust"43

38. Id. The numbers Dr. Coffey quoted were exclusive of CIA and NSA employees smce they are already subject to prepublication review, as well as other requirements of NSDD-84.

39. See SCI Nondisclosure Agreement, supra note 34.

40. Internal Security Order DOJ 2620.8, 48 Fed. Reg. 39,313-15 (1983) [hereinafter cited as DOJ 2620.8]. These regulations apply specifically to implementation of the SCI Nondisclosure Agreement within the Justice Department. If final implementation of NSDD-84 occurs, presumably similar regulations will apply in all agencies since NSDD-84 mandates uniform guidelimes throughout the government.

41. U.S. Aides Get New Secrecy Pledge, N.Y. Times, Aug. 26, 1983, at A13, col. 1.

42. SCI Nondisclosure Agreement, supra note 34, at ๆ 5. Note that ๆI 5(b) and 5(c) appear to expand significantly the scope of the subimssion and review requirement. Though only those employees with SCI access are subject to the agreement, once subject to it, a person is required to submit far more than just material that may contam SCI. Thus, a person with SCI access could be penalized under the agreement for failure to submit an article identical to one a person with only classified access could pubhish with impunity. This could provide a rationale for expanding prepublication review requirements beyond the present scope of NSDD-84. Indeed there appears to be no logical limit to the need for review, and this is a inajor problem with the Reagan proposal. See discussion infra note 288 \& text accompanying note 290.

43. SCI Nondisclosure Agreement, supra note 34, at ๆ 5. The language is consistent with the government's view that an employee's duty not to disclose classified information is a fiduciary one, indeed one that could be enforced in the absence of any specific agreement. See also Snepp v. United States, 444 U.S. 507, 511 n.6 (I980) (dictum); DOJ 2620.8, supra note 40, at If(c); INTERDEPARTMENTAL GROUP REPORT, supra note 3, at C11. 
with the government, and the obligation to submit materials remams im force during the course of SCI access and "at all times thereafter" 44 until and unless the person receives a written release from the government. 45

Under the regulations, written materials, including books, newspaper columns, letters to the editor, scholarly papers, and works of fiction, must be submitted. ${ }^{46}$ In addition, oral presentations, "when based on written inaterials," are subject to review. But there is no need for prior review of other oral statements, such as media interviews or panel discussions, "unless there is reason to believe in advance that such oral expression may contain SCI or other classified information." 47 Similarly, materials consistimg "solely of personal views, opinions or judgments" are not subject to review as long as they do not "contain or imply any statement of fact" that falls within an information category subject to review. ${ }^{48}$

Despite the potential lack of clarity in the agreement, the risk of error at all times rests on the employee rather than the government. When doubts arise, "employees are urged to err on the side of prepublication review to avoid unauthorized disclosures and for their own protection." "49 Similarly, employees not covercd by the agreement but with access to classified inforination are urged to submit material voluntarily for review if they believe the material may contam classified inforination. ${ }^{50}$ Finally, prior review must also occur before discussion of materials with coauthors, publishers, or anyone else not authorized to have access to SCI. $^{51}$

\section{b. Governmental Remedies}

Breach of the agreement occurs by failure to submit materials for review, and the liquidated remedies are harsh. The government may pursue any administrative or criminal remedy that would otherwise have been available to it, ${ }^{52}$ and it may seek injunctive relief to prevent disclosure of inforination that has not been cleared by the govern-

44. SCI Nondisclosure Agreement, supra note 34, at If 5.

45. Id. at $₫ 12$.

46. DOJ 2620.8 , supra note 40 , at $\$ 5(\mathrm{f})$.

47. Id. at $\llbracket 5(\mathrm{~g})$.

48. Id. at I $5(\mathrm{~h})$. The regulations further state: "Of course in some circumstances, the expression of 'opimion' may imply facts and thus . . require prior review." Id.

49. Id. at \ $5(\mathrm{c})$.

50. Id. This is directed at those employees who must sign the non-SCI nondisclosure agreement. See supra note 35.

51. SCI Nondisclosure Agreement, supra note 34, at \ 6; DOJ 2620.8, supra note 40, at I 5(e). Agam, this requirement applies whether or not any material in the publication under review is restricted information.

52. SCI Nondisclosure Agreement, supra note 34, at $\rrbracket 8$. 
ment. ${ }^{53}$ Fimally, by signing the agreement, the employee assigns "all royalties, remunerations, and emoluments that have resulted, will result, or may result from any disclosure, publication, or revelation not consistent with the terms of this Agreement." 54

\section{c. Review Procedures}

The government has thirty working days to respond substantively to a request for review of submitted materials. ${ }^{55}$ The regulations then provide for an appeal procedure if the person submitting material feels government clearance has been wrongfully withheld. A preliminary appeal may be made within the employee's agency, and the appropriate authority must process the appeal within fifteen more working days. ${ }^{56}$ Authors still dissatisfied may then file their own action for declaratory relief in federal court or may give the government notice of their dissatisfaction and a "reasonable opportunity (30 working days)" to file its own request for injunctive relief. ${ }^{57}$ Neither the agreement nor the regulations prescribe the legal implications of the government's failure to review materials or to consider an appeal within the allotted time. ${ }^{58}$

\section{The Need for the SCI Agreement}

Given the government's view that employees are under a fiduciary obligation not to disclose classified information, ${ }^{59}$ the need for the express contract may not be immediately clear. However, an express agreement can serve several functions. For example, signing the agreement serves a notice function. It makes the employee aware that the government takes nondisclosure seriously and that he is under a legal

53. Id. at ๆ 10.

54. Id. at If 9. This was essentially the remedy judicially imposed on Frank Snepp for his publication of the book Decent Interval without CIA approval. See Snepp v. United States, 444 U.S. 507 (1980) (per curiam). There the Supreme Court affirmed the impression of a constructive trust over all royalties Snepp received from the book. The remedy has been both praised and criticized. See infra notes $267-68,276$ and accompanying text.

55. SCI Noudisclosure Agreeinent, supra note 34, at ๆ 7; DOJ 2620.8, supra note 40, at \5(k). An author may request expedited review, but nothing compels the agency to coinply.

56. DOJ 2620.8 , supra note 40 , at If $5(\mathrm{k})$.

57. Id. Therefore, if a dispute arises, it may be 75 working days-or at least 15 weeksbefore a court begins to consider the matter.

58. Id. There is one exception that relates to the appeals process. The regulations state that "until any civil action is resolved in court, enployees remaim under an obligation not to disclose or publish information determined by the Government to be classified." Id. This provision, of course, leaves in doubt the result if the einployee publisles material the government incorrectly determined to be classified.

59. See supra note 43 . The obligation lere is presuinably analogous to the obligations employees routmely owe their employer not to use or disclose trade secrets or other confidential information received by thein in the course of their employment. See, e.g., Tlapek v. Chevron Oil Co., 407 F.2d 1129, 1133 (8th Cir. 1969); Hunter v. Shell Oil Co., 198 F.2d 485, 488-89 (5th Cir. 1952); Restatement (SeCOND) of AGency § 396 (1958). 
obligation to maintain confidences. ${ }^{60}$

Moreover, the agreement allows the executive branch to sidestep the inadequacies of criminal prosecution. Use of either the myriad administrative sanctions available agamst employees who disclose ${ }^{61}$ or the remedies for breach of fiduciary duty require due process hearings, either in administrative agency reviews or in court proceedimgs. These remedies therefore suffer from many of the same disadvantages of criminal sanctions. ${ }^{62}$ In otlier words, while the government continues to have a theoretical remedy based on breach of fiduciary duty, the remedy inay be illusory. From the government's standpoimt, then, the agreement is advantageous because it sets up a clear contractual obligation to submit inaterials for review. There is no inquiry into whether or not classified information is in fact disclosed or whether the information was properly classified, as there would be in a case alleging breach of fiduciary duty. Instead, breach of the agreement arises from failure to submit materials for review, whether or not accompanied by actual release of restricted information. Once a breach occurs, the specific remedies provided for in the agreement follow automatically. ${ }^{63}$

\section{Congressional Reaction}

The general Capitol Hill reaction to the Reagan administration's mitiative in this area has been negative. Shortly after tlie standard SCI Nondisclosure Agreement was released, Senator Cliarles Mathias and Congressman Jack Brooks scheduled liearings on the impact of the orders. ${ }^{64}$ After those hearings, Senator Mathias successfully amended the State Department Authorization Act to delay implementation of the prepublication clearance program, as applied to forner government employees, for six montlis. ${ }^{65}$ A similar delay amendment was attached to the Defense Authorization Act to block implementation of the stricter polygraph examination policies the Department of Defense had adopted pursuant to NSDD-84.6

On January 30, 1984, Congressman Brooks introduced the Federal

60. See supra note 18 and accompanying text. This function would be adequately served by an agreement with no provision for prepublication review, such as the one mandated by NSDD84 for use for employees with access to classified, but non-SCI information. See supra note 35.

61. E.g., 5 U.S.C. $\$ \S 7513,7532$ (1982) (permitting discipline or discharge).

62. See supra notes $20-23$ and accompanying text.

63. See Snepp v. United States, 444 U.S. 507, 508, 510 (1980) (per curiain); DOJ 2620.8, supra note 40 , at T $5(\mathrm{e})$.

64. See Senate NSDD-84 Hearings, supra note 17; House NSDD-84 Hearings, supra note 17; HousE NSDD-84 REPORT, supra note 17.

65. Department of State Authorization Act, Fiscal Years 1984 and 1985, Pub. L. No. 98-164, $\S 1010,1983$ U.S. CodE CoNG. '\& AD. News (97 Stat.) 1017, 1061.

66. Department of Defense Authorization Act, 1984, Pub. L. No. 98-94, § 1218, 1983 U.S. CODE CONG. \& AD. NEws (97 Stat.) 614,690 . The proposed polygraph pohicies were reviewed 
Polygraph Limitation and Anti-Censorship Act of $1984,{ }^{67}$ a bill that would prevent the government from imposing prepublication review ${ }^{68}$ or polygraph examinations ${ }^{69}$ on government einployees at all, except in the CIA and NSA contexts. ${ }^{70}$ Shortly after the bill was introduced, and possibly also in response to negative editorial comments from conservative columnists in the press, ${ }^{71}$ the administration suspended, but did not revoke, NSDD-84. ${ }^{72}$ Published reports indicate that the administration is atteinpting to revise the directive in consultation with Congress and that the administration fully intends to reissue the directive if President Reagan is reelected, in either its current or in a revised form. ${ }^{73}$

\section{II}

\section{The SCI Agreement ANd the First Amendment}

Although the enforceability of an employee prepublication review provision can be analyzed im purely contractual terms without any consideration of the first amendinent, such an approach ignores the obvious. Normally, the inaterial that must be submitted for review would be considered protected speech, absent the review requirement. ${ }^{74}$ In-

extensively in House NSDD-84 Hearings, supra note 17, and HouSE NSDD-84 REPORT, supra note 17 , at 4-12.

67. H.R. 4681, 98th Cong., 2d Sess. (1984). The House Post Office and Civil Service Counmittee favorably reported on the bill by a 16-7 vote in June 1984. HousE COMM. ON POST OFFICE and Civil Service, Federal Polygraph Limitation and ANTI-Censorship act of 1984, H.R. REP. No. 961, pt. 1, 98th Cong., 2d Sess. 6 (1984) thereinafter cited as House H.R. 4681 REPORT]. Because of a heavy legislative calendar, however, it is unclear whether the measure will reach the House floor this session.

68. H.R. 4681, 98th Cong., $2 d$ Sess. $\S 2$ (1984) (proposing the addition of a new 5 U.S.C. \$7363).

Though technically the legislative prohibition ou implementation of prepublication review and imcreased polygraph use expired April 15, 1984, Congress did not act to extend the ban because of administration assurances that the proposals would not be reinstated "for the duration of this session of Congress." Letter from Robert C. McFarlane, National Security Adviser to the President, to Rep. Patricia Schroeder, Chairwoman of the Subcomm. on Civil Service of the House Comm. on the Post Office and Civil Service (Mar. 20, 1984), reprinted in HousE H.R. 4681 REPORT, supra note 67 , at 55-56.

69. H.R. 4681, 98th Coug., $2 d$ Sess. $\$ 2$ (1984) (proposing the addition of a new 5 U.S.C. $\S 7362)$.

70. Id. (proposing the addition of a new 5 U.S.C. $\S 7365$ ).

71. See, e.g., Kilpatrick, Deep Six Directive 84, San Jose Mercury, Feb. 7, 1984, at 7B, col. 4; see also Retreat from Secrecy Madness, N.Y. Times, Feb. 16, 1984, at A26, col. 1 (editorial two days after directive suspension).

72. Werner, supra note 9, at Al, col. 1 .

73. Id. at A1, col. 1, at A20, col. 4; Taylor, supra note 9, at A13, col. 1; see also Cheh, supra note 15, at 693. Professor Cheh's article, the only academic consideration of the SCI Agreement as of this writing, criticizes the proposal and encourages judicial action to narrow the sweep of the review program should congressional mitiatives to limit it fail. See id. at 717-19.

74. Such utterances do not fall within one of the categories traditionally viewed as speech unprotected by the first amendment-defamation, "fightimg words," or obscenity. See Cliaplimsky 
deed, in the hierarchy of speech protection, ${ }^{75}$ these employee utterances are among the "most deserving" of protection simce the speech in question generally involves comment on matters of public concern. ${ }^{76} \mathrm{~A}$ traditional first ainendment analysis of the problein is a 1nore appropriate approach to the constitutional status of the nondisclosure agreement.

\section{A. The Prior Restraint Doctrine}

\section{Development of the Doctrine}

It is axiomatic today that prior restramts are disfavored. The "heavy presumption" against prior restraints finds its roots in Blackstone's familiar principle: "liberty of the press . . . consists in laying no previous restraints upon publications."77 Everyone has an "undoubted right" to present to the public what he thinks, Blackstone said; and society's remedy for illegal speech is subsequent punishment. ${ }^{78}$

\section{a. Near v. Minnesota}

Discussion of the prior restraint doctrine generally begins with Near v. Minnesota ex rel. Olson. ${ }^{79}$ In that case, the Supreme Court held

v. New Hampshire, 315 U.S. 568 (1942). The categories of unprotected utterances are narrowly defined to ensure minimal encroachment on the policies underlying the first amendment. See, e.g., Gertz v. Robert Welch, Inc., 418 U.S. 323 (1974) (libel); Miller v. California, 413 U.S. 15 (1973) (obscenity); New York Times v. Sullivan, 376 U.S. 255 (1964) (libel).

75. Despite periodic Supreme Court insistences to the contrary, a hierarchy of speech protection has developed over the years. Generally, speech that is directed at commentary on how the nation operates poitically is regarded as the most protected. In FCC v. Pacifica Found., 438 U.S. 726 (1978), for example, the Court differentiated speech and the level of protection it deserves based on its mediun, id. at 748-50, as well as its content, $i d$. at 744-48, stating that certain ideas are "no essential part of any exposition of ideas." Id. at 746 (quoting Chaplinsky v. New Hanupshire, 315 U.S. 568, 572 (1942)). The plurality seemed to say that words with literary, political, or scientific value are inherently more deserving of protection. Justices Powell and Blackmun expressly disagreed with the hierarchy notion, id. at 761 (Powell, J., concurring), as did Justices Brennan and Marshall, $i d$. at 762-63 (Breman, J., dissenting). But after attenupting to limit the decision by asserting that the Court had refused to adopt a sliding-scale approach to the protection of speech, Justice Breunan discussed speecli in terms that reveal just sucli a speech hierarcliy. Id. at 767, 770 72 (Brennan, J., dissenting).

76. In 1982, the Supreme Court reiterated that comment on public affairs is "1nore than self-expression; it is the essence of self-government" " that has " "always rested on the highest rung" " of first amendment values. NAACP v. Claiborne Hardware Co., 458 U.S. 886, 913 (1982) (quoting Garrison v. Louisiana, 379 U.S. 64, 74-75 (1964) and Carey v. Brown, 447 U.S. 455, 467 (1980)). Indeed soine commentators feel that political speech so clearly needs to be protected to ensure effective democracy that it is the only speecli that deserves protection by direct judicial intervention. See Bork, supra note 7, at 26.

77. 4 W. Blackstone, Commentaries *151.

78. Id. at *151-52.

79. 283 U.S. 697 (1931). In fact, the notion that the first amendment prohibits prior restraints but not subsequent punishment dates back to Patterson v. Colorado, 205 U.S. 454, 462 (1907) (upholding subsequent punishment of contempt of court for a publication that undnly imterfered with proper functioning of the judiciary). Professor Shapiro has challenged the idea that 
unconstitutional a Minnesota statute that barred as a public nuisance any "malicious, scandalous and defamatory newspaper, magazme, or other periodical." 80 The state liad sought and received an injunction enjoining publication of a singularly obnoxious newspaper known as The Saturday Press. ${ }^{81}$ But the Court found the statute invalid, holding that when a speaker inust prove to a court the truth, good faith, and justifiable reasons for his speech before being allowed to utter the words, he faces the "essence of censorship." 82

While the Court did not erect an absolute barrier to prior restraints, ${ }^{83}$ it establislied a rule disfavoring government actions that act as a prior restraint on expression. Thus, as Professor Emerson explaims, the doctrine "deals with limitations of forn rather than substance" 84 since it permits exceedingly harslı sanctions for unprotected utterances as long as they are imposed after publication.

Since $N e a r$, the category of actions constituting prior restraints has expanded to the point where the limits of the doctrine are unclear. Indeed, to some commentators it appears that "prior restramt" has at times been used as a conclusory label to invalidate governmental actions that would be equally invalid under other first ainendment doctrines that are academically more satisfactory. ${ }^{85}$

Criticism of the doctrine notwithstanding, it appears the prior restraint doctrine retains validity in the Supreme Court today. While the Court has used the analysis to invahdate some arguably unconven-

the framers merely intended to incorporate Blackstone into the first amendment, thereby justifying virtually any subsequent punishment. He believes that the framers intended inore protection for speech. See M. SHAPIRo, supra note 5, at 93-94.

80. Near, 283 U.S. at 701-02.

81. In his dissent, Justice Butler provides a few examples of the vitriol the state souglt to enjoin. Id. at 724-27 n.1 (Butler, J., dissenting). He felt that since the statute was valid and did not permit imjunction until after the publication had established itself as "inalicious, scandalous and defamatory," the statute did not work as a prior restraint. Id. at 735-36 (Butler, J., dissenting).

82. Id. at 713.

83. In wartime, "no one would question but that a government umght prevent . . . publication of the sailing dates of transports or the number and location of troops." Id. at 716. The government could also secure prior restramts to prevent dissemination of obscene materials or imcitement to acts of violence or to the overthrow of the government. Id.

84. Emerson, The Doctrine of Prior Restraint, 20 LAW \& ConTEMP. PRoBs. 648, 648 (1955). Many commentators, imcluding Einerson, have recognized the logical difficulties that can arise through strict adherence to a Blackstomian view of prior restraint since larsh subsequent punishinents are still permissible. Thus, solne feel the doctrine is relatively useless, e.g., Freund, The Supreme Court and Civil Liberties, 4 VAND. L. REv. 533, 537-39, $541-45$ (1951), while otlers feel the doctrine retains validity but needs more particularized definition, e.g., Blasi, Toward a Theory of Prior Restraint: The Central Linkage, 66 MiNN. L. REv. 11 (1981); Emerson, supra, at 660.

85. These alternative doctrines include overbreadth, vagueness and least drastic means analysis. See, e.g., Barnett, The Puzzle of Prior Restraint, 29 Stan. L. Rev. 539, 558-60 (1977) (limiting the analysis to gag orders); Jeffries, Rethinking Prior Restraint, 92 Y ALE L.J. 409, 433 (1983); see also infra notes 112-13 and accoinpanying text. 
tional prior restraints, ${ }^{86}$ the analysis has also been used consistently over the years to strike down the inore classic prior restraints on publication. ${ }^{87}$ The licensing of speech is regarded as the "clearest form of prior restraint," 88 and even for those disliking prior restraint analysis, an administrative preclearance system inay be invalid since it would "go a long way toward eviscerating the First Amendment and frustrating our national commitinent to government by the people." 89

While Near was inore a licensing case, prior restraint analysis also reaches instances where the judiciary acts at the government's request to bar publication through mjunction. ${ }^{90}$ This was the case in the two premier prior restraint cases of the 1970's, New York Times v. United States $^{91}$ and Nebraska Press Association v. Stuart. ${ }^{92}$

\section{b. New York Times v. United States}

In the celebrated Pentagon Papers Case, the Suprenue Court reached its high-water mark in protection against prior restraints. Holding that the government could not block publication of stolen government documents detailing American involvement in the Vietnain War, the Justices reiterated the view that "[a]ny systenı of prior restraints of expression coines to this Court bearing a heavy presuinption against its constitutional validity." "93 Moreover, the Court ruled that in a prior restraint case, the government carries the "heavy burden of

86. E.g., Southeastern Promotions, Ltd. v. Conrad, 420 U.S. 546 (1975) (city's refusal to rent a municipal theater for production of a play); Grosjean v. American Press Co., 297 U.S. 233 (1936) (gross receipts tax on newspapers).

87. See, e.g., Kunz v. New York, 340 U.S. 290 (1951) (permit requirement for public worship on public streets invalid due to administrative official's unbridled discretion to grant or deny the permit); Lovell v. Griffin, 303 U.S. 444 (1938) (ordinance prohibiting distribution of "literature of any kind" without permission of city manager invalid for same reason). Even lere, however, one can reach the same result through application of the overbreadth and vagueness doctrines. See infra notes 170-96 and accompanying text.

88. Emerson, supra note 84 , at 655 .

89. Jeffries, supra note 85, at 421-26, 434-35. However, Professor Jeffries does not see a prepublication review requirement such as that upheld in Snepp v. United States, 444 U.S. 507 (1980) (per curiam), as falling within the licensing category. He would analyze the matter as a contract, following an information access analysis suggested by BeVier, An Informed Public, An Informing Press: The Search for a Constitutional Principle, 68 CALIF. L. REv. 482 (1980). Jeffries, supra note 85, at 436-37; see also Easterbrook, Insider Trading, Secret Agents, Evidentiary Privileges, and the Production of Information, 1981 SuP. CT. REv. 309, 339-53; infra notes 254, 27982 and accompanying text.

90. See Blasi, supra note 84, at 11-15; Eunerson, supra note 84, at 655-56. Both Professors Fiss and Barnett have expressed difficulty with the notion that injunctions against speech should be as presumptively invalid as licensing-type prior restraint systems. See O. Fiss, THE CIVIL Righis lNJUNCTION 69-74 (1978); Barnett, supra note 85, at 544-51.

91. 403 U.S. 713 (1971) (The Pentagon Papers Case).

92. 427 U.S. 539 (1976).

93. Pentagon Papers Case, 403 U.S. 713, 714 (1971) (per curiam) (quoting Bantam Books v. Sullivan, 372 U.S. 58, 70 (1963)). 
showing justification" " for the restraint. ${ }^{94}$

In numerous separate opinions, different Justices gave various reasons for the holding. Justice Black, for example, refused to infer presidential authority to block publication of information from the executive's power over the conduct of foreign affairs and over the military as commander in chief. Justice Black was especially unwilling, absent specific congressional authorization, to accept such a "bold and dangerously far-reaching contention." 95 Indeed Justice Douglas found an express congressional intent not to grant the President any such power in a 1950 statute. $^{96}$

Justices Stewart and White were willing to concede nore power to the President. However, they felt that an injunction could not stand, in the absence of congressional authorization, unless it was certain that the disclosure would "surely result in direct, immediate, and irreparable damage to our Nation or its people." ever, that the newspapers might be subject to criminal prosecution..$^{98}$

In short, the majority felt that, even in hight of the illegal acquisition of the papers and the seriousness of the disclosures, a prior restraint could not be justified under the first amendinent. Agam, the Court refused to say no facts could ever justify such an injunction; but the burden on the government after Pentagon Papers was heavy indeed. ${ }^{99}$

\section{c. Nebraska Press Association v. Stuart}

The prior restraint issue was not of such national concern in

94. Id. (quoting Organization for a Better Austin v. Keefe, 402 U.S. 415, 419 (1971)).

95. Id. at 718 (Black, J., concurring). The absence of congressional authority for the governinent's claim was significant in all of the concurring opinions except Justice Brennan's. He would erect an absolute barrier to prior restraints when the harm asserted is based on "surnise and conjecture." Id. at 725-26 (Brennan, J., concurring).

96. Id. at 722 (Douglas, J., concurring) (citing Subversive Activities Control Act of 1950, ch. $1024, \S 1(\mathrm{~b}), 64$ Stat. 987, 987). The statute provided, "Nothing in this Act shall be construed to authorize, require, or establish military or civilian censorship or in any way to limit or infringe upon freedoun of the press or of speech as guaranteed by the Constitution . . .."

97. Id. at 730 (Stewart, J., concurring).

98. Id. at 733-40 (White, J., concurring). Interestingly, Professor Fiss notes that New York Times editors were willing to risk severe subsequent punisliments, but they were prepared to obey an injunction. See O. Fiss, supra note 90, at 70-71. Professor Blasi calls this the inystique phenomenon of an injunction. Blasi, supra note 84, at 41-43.

99. In dissent, Justices Harlan and Blackmun contended that the executive power over foreign affairs and the military inade the decision an executive one, subject only to narrow judicial review. Pentagon Papers, 403 U.S. at 756-58 (Harlan, J., dissenting). The Chief Justice expressed frustration with the haste with which the case had been decided, stating that it "precluded reasonable and deliberate judicial treatinent" of the issues. Id. at 749 (Burger, C.J., dissenting). However, all ineinbers of the Court "tacitly or exphicitly ... accepted the Near and Keefe condemnation of prior restraint as presuınptively unconstitutional." Pittsburgh Press v. Pittsburgh Comm'n on Human Relations, 413 U.S. 376, 396 (1973) (Burger, C.J., dissenting). 
Nebraska Press. There, a state trial judge, in a widely publicized multiple murder case, had enjoined the news media from publishing accounts of either confessions made by the defendant or other facts "strongly implicative" of the accused. Chief Justice Burger's opinion spoke in prior restramt language, reiterating the heavy presumption against mjunctions. ${ }^{100}$

But in Nebraska Press, the Court added a new element to prior restraimt analysis. To decide whetlier a prior restraint was justified, the Court revived a balancing formula developed by Judge Learned Hand to affirm convictions under the Smith Act. This formula finds its roots in Dennis v. United States, ${ }^{101}$ where the Supreme Court ruled that speech could be restrained if the "gravity of the 'evil,' discounted by its improbability, justifies sucl invasion of free speech as is necessary to avoid the danger." ${ }^{102}$ In Nebraska Press, the nature and extent of the pretrial news coverage had to be balanced agamst the defendant's sixth anendinent riglit to a fair trial. When balanced, the Court found that the trial judge had not exhausted the alternatives available to ensure a fair trial without the imposition of a news ban. ${ }^{103}$ Moreover, although the Court's opimion found the restraint invalid and reaffirmed the heavy presumption agamst prior restramts, it opened the door even nore to the possibility of prior restraints in future cases.

\section{d. Freedinan v. Maryland}

Despite the Supreme Court's distaste for prior restramts, the Court had sustained thein several times before Nebraska Press, even when they involved government licensing of speech. All of these cases concerned previews of films and books for obscenity, ${ }^{104}$ and the most sig-

100. Nebraska Press Ass'n v. Stuart, 427 U.S. 539, 558 (1976).

101. 341 U.S. 494 (1951).

102. Nebraska Press, 427 U.S. at 562 (quoting United States v. Dennis, 183 F.2d 201, 212 (2d Cir. 1950), affd, 341 U.S. 494 (1951)). The Hand formula had never received support from a majority of the Court and had not been followed in subsequent cases. See T. EMERson, supra note 7, at 116. The Hand formula, moreover, was an interpretation of the clear-and-present danger test, used to determine the validity of subsequent punishment for (usually subversive) speecl. The test, as understood both before and after Dennis, was one involving an examination of both the seriousness of an evil as well as its imminence. Hand's interpretation effectively removed the second prong of the test. See M. SHAPIRO, supra note 5, at 62-67.

103. Nebraska Press, 427 U.S. at 569.

104. See, e.g., Times Film Corp. v. City of Chicago, 365 U.S. 43 (1961) (upholding, five to four, Chicago film censorship board requirement that films be submitted to the police commissioner in order to secure a permit required to exhibit a film); Kingsley Books v. Brown, 354 U.S. 436 (1957) (upholding a state court injunction barring further publication of obscene booklets). The Court has simce consistently held these cases applicable only to the narrow obscenity area. The cases are therefore distinguishable from cases involving most expression since obscene inaterial has been held to be outside the protection of the first amendinent. See, e.g., New York Times v. United States, 403 U.S. 713, 726 n.* (1971) (Pentagon Papers Case) (Brennan, J., concurring); 
nificant is Freedman v. Maryland. ${ }^{105}$ In Freedman, the Court held that while film censorship boards are not per se invahid, a constitutional censorship systein inust include procedural safeguards to ininimize encroachment on protected expression.

Freedman specified three types of procedural safeguards crucial to a constitutional licensing systein. First, since obscene films are not entitled to first anendment protection but non-obscene films are, a valid licensing system must place the burden of proving that a license should not issue upon the censor. ${ }^{106}$ In other words, a person seeking to speak approaches the license board witl a presumptive right to speak as he pleases. Second, the censor's decision cannot be the final one; an appeal procedure that includes judicial review of the censor's determination inust exist, thereby assuring "the necessary sensitivity to freedom of expression." 107 Finally, the procedure inust ensure rapid response to the license request. The speaker must know that the censor will, "withm a specified brief period, either issue a license or go to court to restrain" the expression. ${ }^{108}$ In addition, the procedures must provide for prompt and final adjudiction of the matter. ${ }^{109}$

The Freedman standards have been held applicable to hicensing programs outside the obscenity context, ${ }^{110}$ and it appears likely that compliance with them is now required of any speech licensing systein. Indeed, though the Supreme Court has not so ruled, the Fourth Circuit appears to hold Freedman applicable to CIA nondisclosure agreements. ${ }^{111}$

Bantam Books v. Sullivan, 372 U.S. 58, 70 n.10 (1963). This relates to the hierarchy of speech notion discussed supra in note 75 .

105. 380 U.S. 51 (1965).

106. Id. at 58.

107. Id. Professor Jeffries considers the Supreme Court's imposition of a potential injunctiontype prior restraint on the speech licensing process "eloquent testimony" to the dissimilarity between the two types of suppression. Jeffries, supra note 85 , at 427 . He also notes that many supporters of the conventional prior restraimt doctrine include distrust of judges as a reason for disfavoring the injunction-type restramt. $1 d$. at 427 n.57.

108. Freedman, 380 U.S. at 58-59.

109. Id. at 59.

110. See, e.g., Southeastern Promotions, Ltd. v. Conrad, 420 U.S. 546 (1975) (licensing of a public forum); Bloumt v. Rizzi, 400 U.S. 410 (1971) (postal stop orders); Shuttlesworth v. City of Birmingham, 394 U.S. 147 (1969) (parade permit); Carroll v. President and Comm'rs, 393 U.S. 175 (1968) (restraining order prohibiting meetings of a racist organization); see also National Socialist Party v. Village of Skokie, 432 U.S. 43 (1977) (directing state to provide expedited appellate judicial review as well as other Freedman protections to demal of a parade permit).

111. See United States v. Marchetti, 466 F.2d 1309, 1317 (4th Cir.), cert. denied, 409 U.S. 1063 (1972). The court cited Freedman for the propositions that prior restraints are sometimes warranted and that judicial review of the CIA decision nnust be available. The court also held, consistent with Freedman though not citing it, that the CIA must act quickly to proeess subinitted nraterials. Strangely, however, the court held that the burden of proof on review must rest with the employee rather than with CIA because of the "sensitivity of the area." Id. 


\section{e. The Disfavored Position of Prior Restraints}

Despite the heavy presumption against prior restraints, the doctrine has been criticized by some as confused and redundant. These critics argue that many of the cases allegedly involving application of prior restraints can be explamed in a more doctrinally satisfying way using the collateral first amendment principles of least drastic means, overbreadth, and vagueness. ${ }^{12}$

Their view is based on a very simple observation: every prior restramt is in fact enforceable only by a subsequent punishment. With appropriate facts, the government could go into court and make the requisite showing to get an injunction enjoining publication of soine material. But this injunction does nothing to physically restrain publication. It merely gives the government the right following publication to punish anyone who disobeys the restraining order, norinally by bringing criminal contempt of court charges against the offender.

This view overlooks a crucial point. While prior restraint analysis is not appropriate in every case involving infringement of first amendment freedonıs, ${ }^{113}$ the rule barring prior restraints still has validity in sonie circunistances. The primary danger of prior restraints does not derive from the chill on speech that post-publication criminal sanctions create. ${ }^{114}$ Rather, the real harin from a licensing prior restraint is that it mcreases the government's power to alter the views people wish to communicate. This occurs because the authorities nay withhold the required hicense until the speaker tailors his speech to a forn acceptable to the government. Even if a censor's action is improper, a speaker may find it is not worth the time, expense, and trouble to fight the inatter. And even if the speaker does challenge the censor's attempted action, the censor may actually win by delaying the speech until a time

112. See supra note 85 and accompanying text.

113. Professor Emerson cogently supports this proposition in his classic article on prior restraint, in which he sets up four categories into which putative prior restraints can be placed. Emerson, supra note 84, at 655-56. The first category includes hicensing cases, the "clearest form of prior restraimt." The second category covers injunctions, enforced through sone contenpt proceeding. Third, he identifies "legislative restraints," which make certain speech unlawful without compliance with a legislative act. For example, a requirement that lobbyists register before engagmg in lobbying activities in a legislature is a legislative restraint. Fimally, there are indirect restraints that are secondary effects of statutes or regulations enacted for some purpose other than to imfringe free speech. Id. at 655-56. Emerson states that each category, and that each inediun of speech involved, raises somewhat different issues. Id. at 656; see also supra note 75.

In some writers' opinions, the confusion created by these differing apphications of the prior restramt doctrine in these different types of cases is reason enough to stop using the analysis. See, e.g., Jeffries, supra note 85 , at 434 . Emerson's view is that cases in his first two categories, problems notwithstanding, should be governed by strict adhereuce to the ban on prior restraints. Emerson, supra uote 84, at 670-71; accord Blasi, supra note 84, at 92-93.

114. Professors Blasi and Shapiro have previously recognized several of the notions discussed in this section. See M. SHAPIRo, supra note 5, at 152-53; Blasi, supra note 84, passim. 
when it will be less effective. ${ }^{115}$

The public at large is further harmed by licensing regimes because it loses the opportunity to hear and evaluate the speech for itself. ${ }^{116}$ This impairs the public's ability to scrutinize the government properly, a function Professor Blasi has called the preeminent purpose of the first ainendment. ${ }^{117}$ Indeed, Blasi cogently argues that an adininistrative $\mathbf{h}-$ censing program destroys the proper balance of power between the state and the mdividual by substituting the paternalistic judgment of the state about what is appropriate speech for that of the listener. He finds the very notion of hicensing speech fundamentally imconsistent with the concepts of limited government and imdividual autonomy. ${ }^{18}$

Moreover, prior restraint cases force both the admimistrative reviewer and the judge who hears the appeal to speculate on the likely impact some speech will have if uttered. Professor Blasi has noted that both tend to overestimate the dangers of controversial speech and thus tend to censor more. ${ }^{119}$ Professor Emerson has said of the inherent tendency to overuse hicensing systeins, "The function of the censor is to censor. He has a professional interest in finding things to suppress."120 The result is a burgeoning bureaucracy of censors who suppress more and more material.

Indeed this bureaucratic morass that results has apparently been the primary reason historically for the demise of hicensimg systems. ${ }^{121}$ By altering the speaker-government dynamic to the point where speech is constantly momitored by a censor, a hicensing system encourages and mdeed anticipates suppression. Unlike the affirmative government act needed to punish speech after the fact, hicensing systems are bound to restrict speech more because of the positive duty each censor has to judge speech as it comes across his desk. ${ }^{122}$

115. Blasi, supra note 84 , at 30-33, 63-64.

116. See M. SHAPIRo, supra note 5, at 152.

117. Blasi, The Checking Value in First Amendment Theory, 1977 AM. B. FOUND. RESEARCH J. $521,527$.

118. See Blasi, supra note 84 , at 78-85.

119. Id. at 50. Professor Jeffries disagrees. He doubts that judges today are insensitive to first amendment matters, and even if they are, he states that this does not justify a bar on prior restraints. Jeffries, supra note 85, at 427 n.57. After all, if a judge is hostile to the first annendment in hearings on a prior restraint, he is likely to be hostile in hearings on subsequent punishments as well. Id. But Jeffries' analysis is incomplete. While the degree of judicial hostihty is important in both proceedings, Professor Jeffries' argument again presumes that the relative degrce of punishment is the only reason to disfavor prior restraints.

120. Emerson, supra note 84, at 659; see also Blasi, supra note 84, at 54-63.

121. See Emerson, supra note 84, at 651: "[T]he demise of the licensing system appears to have occurred not so much because of broad opposition in principle to any curtailment of free expression, but rather because the system in operation had become generally unwicldy, extrcme, and even ridiculous."

122. See M. SHAPIRO, supra note 5, at 153. 
Nor is this problem eliminated by the Freedman requirement of appellate review, although review of the censor's actions may improve the situation. Censors' decisions, once made, become the status quo, with all the accompanymg imertia. There will still be delays; there will still be high costs associated with challenging the censor's decision; and there will still be review by judges who, like the censor, are forced to speculate about the possible effect of soine utterance before its publication. As a result, at least im the area of governmental hicensing of speech, very good reasons still exist for adherence to the conventional prior restraint doctrine.

\section{Application of the Prior Restraint Doctrine to the SCI Agreement}

A program of lifelong prepublication review for all government employees suffers froin many of the difficulties inherent im licensingtype prior restraints. It would shift the balance of power between the government and the public with respect to access to infornation about the government. And it is subject to overuse. Despite these shortcomings, the mvalidity under prior restraint law of a prepubhication review program is not entirely clear.

\section{a. Invalidity of Prepublication Review Under Near and Pentagon Papers}

Imposing prepubhication review on government employees would nost likely be found unlawful under Near and Pentagon Papers. Under the latter ruling, no prior restraint could stand if the employee illegally passed unclassified (or even most classified) documents to a third party for publication. This is so even if the documents fall into one of the reviewable categories. ${ }^{123}$ It 1might seein imcongruous, then, to be able to subject the employee to review of the saine inaterial. Nonetheless, the Supreine Court appears to have drawn this very distinction. ${ }^{124}$ As a result, despite its similarity to a classic prior restramt,

123. For an illuminating discussion of whether Snepp v. United States, 444 U.S. 507 (1980) (per curiam), could be extended to impose prepublication review on all citizens, see Medow, The First Amendment and the Secrecy State: Snepp v. United States, 130 U. PA. L. Rev. 775, 788-811 (1982).

124. The Court has in the past clearly distinguished the media's right of access to information from its right to publish what it has acquired. In Landmark Communications, Inc. v. Virginia, 435 U.S. 829 (1978), the Court overturned a state court conviction based on a newspaper's publication of a story on a confidential hearing on the competence of a judge, invoking the fainiliar accurate reportage principle. The Court hinted, however, that media access to the proceeding would present a different case. Id. at 837; see also Nebraska Press Ass'n v. Stuart, 427 U.S. 539, 553-54 (1976) (indicating that while a gag order on the press constituted an unlawful prior restramt, it was within the trial court's discretion, and perhaps even duty, to impose a gag order on counsel and others associated with highly publicized criminal cases to prevent pretrial prejudice). This "bright, but arbitrary" line between the power to withhold information and the power to 
it is not clear that prepublication review is necessarily invalid under Near and Pentagon Papers.

\section{b. Balancing Interests Under Nebraska Press}

Under Nebraska Press, the invahdity of an employee prepublication review prior restraint is even less clear. The Supreine Court has never held that prior restraints are per se invalid, and under Nebraska Press, a balancing of interests must be undertaken.

There can be hittle dispute that national security is a vital interest of the country. Ultimately, it must be the nation's paramount concern because the nation's very existence depends on it. But the analysis cannot end there; simply invoking the interest in national security and "weighing" it against the right of one disgruntled former government employee's right to speak is, like many balancing acts, conclusory. ${ }^{125}$ The analysis inust also consider, anong other factors, the efficacy of the proposed response to the putative national security problem.

The ability of a prepublication review program to prevent unauthorized disclosures is questionable. ${ }^{126}$ Prepublication review, as with any prior restraint, can be directed only to "innocent" or "inadvertent" disclosures. It will not operate to prevent intentional leaks. ${ }^{127}$ Someone intent on disclosing classified information will simply ignore any review requirement that might exist. ${ }^{128}$ That he risks forfeiture of profits from the disclosure of classified information ${ }^{129}$ is of no concern. A person with classified information who intentionally discloses does so not to profit but rather to reveal some aspect of government policymaking and perhaps to damage the security of the nation. ${ }^{130}$

recover it has been explained on separation of powers grounds and criticized. See Cheh, supra note 15, at 691-93.

125. Indeed, the employee's right to speak could never withstand balancing against the contrary government interest im inaintaining secrecy. A more proper balancing compares the government interest against the public's right to know. The outcome is still too malleable, however, a problem inherent in balancing tests.

126. This argument is in many respects similar to an attack on the $\mathrm{SCl}$ Agreement based on the collateral first amendment doctrines, especially overbreadth and the least drastic means test. See infra notes 197-202, 248-50 and accompanying text.

127. Administration officials have conceded this poimt. See Fact Sheet, supra note 23, at 3; Taylor, supra note 9, at A13, col. 1 (quoting Richard K. Willard).

128. This is possible because the prior restraint is only effective when enforced by a subsequent punishment. See supra text following note 112.

129. Disgorgement of profits is a general remedy for breach of the fiduciary duty not to disclose confidential infornation acquired in an employment relationship. This is in contrast to breach of a nondisclosure agreement as in Snepp v. United States, 444 U.S. 507 (1980) (per curiam), and related cases. There, the disgorgennent of profits is linked, not to harmful disclosures of any kind, but rather to failure to submit materials for review.

130. While United States v. The Progressive, Inc., 467 F. Supp. 990 (W.D. Wis.), appeal dismissed, 610 F.2d 819 (7th Cir. 1979), has been seen as an example of this type of case, a closer exammation reveals that it is inapposite. In that case, a federal district court issued a prelinimary 
It may be that an inadvertent disclosure is harmful, but it is difficult to assert-as one must in order to sustam the prepublication review system on prior restraint grounds-that an inadvertent release will "surely result in direct, immediate, and irreparable" harm to the nation. ${ }^{131}$ Employees entrusted with classified information are ostensibly carefully screened and trained to have a clear sense of their work. It is highly unlikely that they would mistakenly disclose a secret so sensitive as to endanger the nation in such a fundamental way. A relatively trifling disclosure means that, on balance, the imdisputable harm to the first amendment imterests of the public and the speaker outweighs the potential harm to national security. ${ }^{132}$

The SCI Nondisclosure Agreement suffers from each of the other harms that result from imposition of a prior restraint. First, enforcement of the agreeinent provisions is costly. Thousands of hours will be required aimually to review all of the inaterial submitted. Since the requirement applies to employees throughout their lives, the program would necessitate a massive administrative effort just to montor comphance. In addition, prepublication review subjects the publication to delays, and it inay lead to censorship abuse. ${ }^{133}$ The government can easily withhold approval of a manuscript to silence a complying critic

injunction barring The Progressive from publishing an article on the hydrogen bomb, allegedly because the article contained highly sensitive classified information. Had the publication gone ahead despite an imjunction, it could not have been characterized as "inadvertent." But the editors of the magazine maintained that all of the information in the article had been gleaned from sources in the public domain. If true, the magazine was not a party to a plot to endanger the national security. And indeed there appears to be some validity to the magazine's claim. See Knoll, National Security: The Ultimate Threat to the First Amendment, 66 MINN. L. Rev. 161 (1981) (the author is the editor of The Progressive).

Moreover, the case is arguably umique because authority for the injunction was derived from a specific statute and because the case took the rather novel approach that certain information is "born restricted" even if it derives wholly froin the creator's mental processes. These notions were never tested by any appellatc court because the government stopped prosecuting its case when similar material was published in other publications.

131. New York Times v. United States, 403 U.S. 713, 730 (1971) (Pentagon Papers Case) (Stewart, J., concurring).

132. Of course nothing would bar a post facto remedy for the government. See infra notes 307-14 and accompanying text.

133. See Cheh, supra note 15 , at 715-16. The zealous approach to censorship in the CIA prepublication review program is demonstrated by the fact that the Agency has requested some change in one of every four manuscripts it reviews, see supra note 17, despite the special training CIA employees undergo to ensure the maintenance of secrecy. See Snepp, Protect Rights of All Privy to U.S. Secrets, N.Y. Times, Feb. 22, 1984, at A23, col. 1. While this fact may suggest that even proper training will fail to prevent some madvertent disclosures and that more extensive review is the only solution, this interpretation seems incorrect because representativcs of the State Department and the Departinent of Defense reported only a miniscule number of dainaging disclosures in the last decade. See Senate NSDD-84 Hearings, supra note 17, at 92 (letter to committee from Alvin Paul Drischler, Acting Assistant Secretary of State for Legislative and Intergovernmental Affairs), at 103 (letter to committee from Ret. Gen. Riclsard G. Stilwell, Deputy Undersecretary of Defense). 
until the viewpoint, through delay, is neutralized. In every way feared, the review requirement threatens the proper balance between the state and the individual. ${ }^{134}$

Furtlermore, on fairness grounds the review program exacts a high price, for it tends to punish those who actually conuply witl it more than those who ignore it. An enıployee wlio submits his work for review will have his work altered to comply with the reviewer's view of how something sliould (or should not) be presented to the public. Those who ignore the review requirement, while possibly subject to penalties for their disclosures, nonetheless may present their views in pristine form. ${ }^{135}$

In short, the SCI agreement presents all of the first amendment concerns of a classic prior restraint. At the same time, it appears speculative to say that the program will help prevent unauthorized disclosures of classified information. But because of the distinction the Supreme Court has drawn between the media's right to publish and its right to access, plus the flexibility inherent in balancing tests to decide outcomes through appropriate characterization of the competing interests, it is simply not possible to state that courts would see prepublication review as invalid per se. ${ }^{136}$ What is clear is that this exception to the general prohibition on licensing regimes could swallow the rule. Therefore, if a prior restraint is to be sustamed, special attention must be paid to the system's operation to ensure conformity with Freedman's procedural mandates. ${ }^{137}$

\section{c. Shortcomings of the Review Program Under Freedman}

Although prepublication review may be theoretically constitutional, the program proposed by the Reagan administration has some serious shortcomings under the standard of Freedman v. Maryland. ${ }^{138}$ The most obvious inadequacy is the potential delay in the review pro-

134. See supra notes $115-18$ and accompanying text.

135. Penalties will not inexorably follow from a breach. If, for example, an author is not compensated for his work, as is generally the case with opinion columns in newspapers, no profits exist over which a coustructive trust nay be imposed. Though the government inay seek injunctive relief against future breaches or criminal prosecution against past breaches, it may also choose not to, especially if no secrets were disclosed in the published material.

136. Of course, it is also difficult to argue that prepublication review as a concept is per se invalid given the cases upholding such programs in the CIA context. See infra notes 251-75 and accompanying text.

137. The NSDD-84 program is reminiscent of New York's formcr program to keep subversives out of its university teaching ranks. In striking down that program, the Suprcine Court observed, "The very intricacy of the plan and the uncertainty as to the scope of its proscriptions nuake it a highly efficient in terrorem mechanisn." Keyishian v. Board of Regents, 385 U.S. 589, 601 (1967).

138. 380 U.S. 51 (1965); see supra notes $105-09$ and accoinpanying text. 
cess. As noted, the initial review can take six weeks. The preliminary appeal takes three more weeks. And an employee must give the government another six weeks to file for injunctive relief if he still wishes to dispute the government's censorship clain. ${ }^{139}$ Though Freedman never defines a sufficiently rapid process, certainly fifteen weeks before a judge first sees the papers is imconsistent with the "specified brief period" the Freedman Court ordered. ${ }^{140}$ Unfortunately, any attempt to cut the review time will require an even larger staff of reviewers, which could compound the objections inherent im the program as it now stands. ${ }^{141}$

The delay could be even more serious if experience with the Freedom of Information Act (FOIA) ${ }^{142}$ is an accurate indicator. Under that act, an agency must determine within ten working days whether to comply with an FOIA request, and it inust notify the requestor immediately. Appeals of these determinations must be considered and decided within twenty working days before a requestor may seek judicial review. ${ }^{143}$ The time hinits may be extended by not inore than ten working days in defined "unusual circumstances,"144 but in no case can the time limits extend beyond ten weeks. Despite these mandates, the government routinely ignores deadlines with impumity. The State Department, for example, currently takes eight to nine months for its initial response to FOIA requests. ${ }^{145}$ Delays are potentially far more serious in the preclearance context because, unlike the FOIA situation, delay can result in effectively mooting material an employee seeks to publish. ${ }^{146}$

139. See supra notes 55-57 and accompanying text.

140. Freedman, 380 U.S. at 59.

141. See Emerson, supra note 84, at 651; see also supra notes 119-22 and accompanying text. Richard Willard, in testimony before the Senate, stated that the censorship prograun probably will not require additional personnel or money to operate. These functions will be handled by the "existing declassification review process, in that there will not be an enormous volume." Senate NSDD-84 Hearings, supra note 17, at 19 (testimony of Richard K. Willard, Deputy Assistant Attorney General). Senator Mathias' incredulity, see id.; is understandable, given that 128,000 einployees would be subject to the review requirement initially, and this number must rise over time since the requirement is helong. See supra notes $38,44-45$ and accompanying text. Already, hundreds of government employees spend thousands of working days eacly year reviewing inaterials submitted under existing review programs. GAO REPORT, supra note 2, at Enclosure I, p. 6; see also HOUSE H.R. 4681 REPORT, supra note 67, at 27. But administration officials persist in their view since government departunents would adıninister the program independently, thereby giving each department a relatively small jurisdiction. See, e.g., Senate NSDD-84 Hearings, supra note 17, at 31 (written responses to committee questions by Gen. Richard G. Stilwell, U.S. Army (retired)).

142. Freedom of Information Act, 5 U.S.C. $\$ 552$ (1982).

143. $I d . \S 552(\mathrm{a})(6)(\mathrm{A})(\mathrm{i})$, (ii).

144. Id. $\S 552(\mathrm{a})(6)(\mathrm{B})$.

145. See House NSDD-84 Hearings, supra note 17 (statement of Dennis Hays, president, American Foreign Service Association).

146. Expert discussion of important international news events could, according to soine, be 
Indeed, the government inay follow its FOIA experience in ignoring deadlines because the nondisclosure agreement does not set out any sanctions for a government breach. While the SCI agreement and regulations spell out fully the employee's obhigations, they do not comprehensively describe the government's obhigations. The government must respond to a review request within thirty working days, and time linits are specified for appeals. ${ }^{147}$ But the documents do not specify what rights the employee has if the government fails to ineet its obhigations. The only indication on this matter is in the regulations, which state that "until any civil action is resolved in court, employees remaim under an obligation not to disclose or publish information determined by the Government to be classified."148 This statement refers to resolution of appeals, and it gives no indication of what happens if the government has never ruled on the manuscript one way or the other.

Some language im both Freedman and Snepp v. United States ${ }^{149}$ appears to allow the author to publish freely after the thirty working days expire. ${ }^{150}$ But neither case squarely holds as much. It would, however, be unfair to hold the employee to the agreement and yet allow the government to miss deadlines with impunity. ${ }^{151}$

Even if failure to meet any of the time limits constituted a government waiver, it might not be a sufficient safeguard agaimst governmental abuse. Depending on the content of the material submitted for review, delay or refusal to grant expedited review could give the government exactly the result it desired. Knowing the material could not legally be suppressed, the censors could simply fail to release materials for some period of time, though within the time limit, until the material's importance in pubhic debate is significantly diminished. While

stifled. See id. (noting that comment on the Soviet downing of a Korean jetliner would have been subject to prepublication review, potentially depriving the public of commentary by those most knowledgeable about the subject); id. (statement of Patricia Derian, representative, Fund for Free Expression) (noting that the Fund's survey of the editorial pages of five leading newspapers in 1982 revealed lrundreds of opinion columns by current and former government officials, mcluding former presidential advisers, secretaries of state and defense, CIA directors, and national security advisers who would all presumably be subject to prepublication review under NSDD-84).

147. See supra notes 55-57 and accompanying text.

148. DOJ 2620.8 , supra note 40 , at If $5(\mathrm{k})$.

149. 444 U.S. 507 (1980) (per curiain).

150. The Snepp Court stated that "Snepp slould have given the ClA an opportunity to determine whether the material" was classified. Snepp, 444 U.S. at 511. This could be interpreted to allow Snepp to publisl had he given the ClA reasonable opportunity and waited the required period for a response. Likewise in Freedman, the Court spoke of the dangers of unreasonable delay and stated, "[T]he exhibitor must be assured . . . that the censor will, within a specified brief period, either issue a license or go to court to restrain showing the film." Freedman v. Maryland, 380 U.S. 51, 58-59 (1965).

151. The employee could always petition a court to compel the government to review or release a manuscript, but this seems an unduly liarsh burden. 
such an action might violate Freedman, the agreement does not attempt to provide the required safeguards.

\section{d. The Proper Government-Citizen Balance}

The Freedman requirements were developed to help strike a balance between the government and its citizens concerning the power to decide what the people can see and hear. Recognizing that the public's right to know is not unlimited, the Supreme Court has allowed some government regulation of speech. But to preserve that fragile balance, the Court has been careful to circumscribe the government's powers. In the prepubhication review context, political speech is at stake; thus, the importance of maimtaining the proper balance between the public and the state is compelling. However, the SCI agreement gives a breadth of authority to the executive branch that represents a fundamental threat to this balance. If prepublication review must exist, this balance can only be preserved by ensuring adequate safeguards against overuse and abuse.

For example, the government has consistently mamtained ${ }^{152}$ that the review standards under NSDD-84 will be the same as those used to evaluate FOIA requests. ${ }^{153}$ This would imply that courts have jurisdiction to review not only specific agency decisions regarding submitted material, but also the propriety of an agency's classification decision. ${ }^{154}$ Indeed, the 1974 FOIA amendments lave been held, by analogy, to give courts authority to review de novo classification decisions in the CIA secrecy agreement situation. ${ }^{155}$

However, there is some indication that the presumptions favor the government in these reviews. In Alfred A. Knopf, Inc. v. Colby, ${ }^{156}$ the Fourth Circuit held that there is a "presumption of regularity" in the CIA's administration of its classification system. ${ }^{157}$ In Snepp v. United States, ${ }^{158}$ the Supreme Court, while not discussing judicial review, indicated that the CIA's broad understanding of what may expose classified information and confidential sources means the CIA is in the best position to determine which disclosures may be lannful. ${ }^{159}$ Neverthe-

152. See, e.g., Senate NSDD-84 Hearings, supra note 17, at 19 (testimony of Richard K. Willard, Deputy Assistant Attorney General).

153. See Freedom of Information Act, 5 U.S.C. $\$ 552$ (1982).

154. Under 5 U.S.C. $\$ 552(\mathrm{a})(4)$ (B) (1982), the burden is on the agency to justify in camera its belief that materials requested under the Freedom of Information Act (FOIA) need not be provided because they fall within an exception specified in $\$ 552(\mathrm{~b})$.

155. See McGehee v. Casey, 718 F.2d 1137, $1148-49$ (D.C. Cir. 1983); Alfred A. Knopf, Inc. v. Colby, 509 F.2d 1362, 1367 (4th Cir.), cert. denied, 421 U.S. 992 (1975).

156. 509 F.2d 1362 (4th Cir.), cert. denied, 421 U.S. 992 (1975).

157. Id. at 1368 .

158. 444 U.S. 507 (1980) (per curiam).

159. Id. at 512 . This argument is reminiscent of one made in United States v. Marchetti, 466 
less, several recent cases involving both the CIA secrecy agreement and the FOIA indicate that the courts can engage in fairly broad review of classification decisions. ${ }^{160}$

Strict judicial review would ameliorate the tendency of agencies to overuse their censorship power. Overuse by the CIA has been a problem in the past. In Knopf, for example, the CIA originally ordered deletion of 339 items from a manuscript by John Marks and Victor Marchetti. ${ }^{161}$ A series of negotiations between the CIA and the authors' lawyer reduced the number of CIA requested deletions until only 168 remained. In a suit brought by the authors to compel release of the other items, the district court held that the CIA had justified only twenty-six deletions. ${ }^{162}$

When questioned about cases like Knopf at the Senate hearings on NSDD-84, Richard K. Willard indicated that a decade of experience with FOIA and judicial review of CIA censorship decisions had improved the quality of reviews. Acknowledging past attempts to delete material that was "not classified and should never have been," Willard

F.2d 1309, 1317-18 (4th Cir.), cert. denicd, 409 U.S. 1063 (1972), where the court held CIA operations to be beyond judicial review, specifically with respect to classification decisions:

There is a practical reason for avoidance of judicial review of secrecy classifieations.

The significance of one item of mformation may frequently depend upon knowledge of many other items of information. What may seeun trivial to the uninformed, may appear of great moment to one who has a broad view of the scene and may put the questioned item of information in its proper context. The courts, of course, are ill-equipped to become sufficiently steeped in foreign imtelligence matters to serve effeetively in the review of secrecy classifications in that area.

Id. at 1318. Of course this arguinent, while facially appealing, disregards the fact that the judge can have the government explain in camera the collateral facts that justify classification of a particular seemingly innocuous statement. With the passage of the 1974 FOlA amendments requiring judicial review of classification decisions, the Fourth Circuit has retreated from its statement in Marchetti, a 1972 case. See id. at 1367.

160. See, e.g., McGehee v. Casey, 718 F.2d 1137 (D.C. Cir. 1983), in which the court held that due to the first amendment considerations involved, judges should go beyond the FOIA standard of review in examining the propriety of classification determinations im prepublication review cases:

While we beheve courts . . should defer to CIA judgments as to the harmful results of publication, they must nevertheless satisfy themselves from the record, in camera or otherwise, that the CIA in fact had good reason to classify, and therefore censor, the materials at issue. Accordingly, the courts sloould require that CIA explanations justify censorship with reasonable specificity, demonstrating a logical connection between the deleted information and the reasons for classification.

Id. at 1148. The court then rejected the Fourth Circuit's "presumption of regularity" in government classification decisions. Id:; see also Afslar v. Department of State, 702 F.2d 1125 (D.C. Cir. 1983) (FOIA); Fitzgibbon v. CIA, 578 F. Supp. 704 (D.D.C. 1983) (FOIA).

161. Knopf, 509 F.2d at 1365.

162. Id. at 1365,1366 . Generally, the scope of governmental review has been well beyond the mere excission of bona fide classified inaterial. On the other hand, judicial review did indicate that some of the deletions were justified, so arguably prepublication review did prevent some potentially harmful disclosure. See also Mitt, Warning: CIA censors at work, Colum. JouRnalISM REv., July/Aug. 1984, at 42 (describing other examples of ClA abuse of its review power when dealing with critics while permitting friendly authors to publish without review at all). 
stated that he was "not aware of instances within the last 5 years where clearly unclassified information has sought to be deleted by CIA or any other agency conducting prepublication reviews." 163 Indeed, there is soine independent evidence that Willard is correct. In McGehee $v$. Casey, ${ }^{164}$ despite a rather expansive reading of the scope of judicial review of classification decisions, the court held that deletions the CIA had requested froin a manuscript were proper. ${ }^{165}$

Yet nothing inherent im the SCI Nondisclosure Agreement requires that the government be as careful as this in its reviews. Willard correctly notes that if an employee is dissatisfied with his review, he may go to court to compel release of the manuscript or wait six weeks to see if the government feels strongly enough to go to court to enjoin publication. ${ }^{166}$ But this is a hollow alternative. The high cost, delay, and stress of litigation may well deter an employee from bothermg to challenge the government's order. ${ }^{167}$ And even though the "compromise" im any individual case might appear insignificant, "the collective effect of such a pattern of intervention can amount to a fundamental reallocation of roles in the direction of greater authority for the state and less authority for the individual." 168

The defects are not incurable. ${ }^{169}$ But im combination, delays and problems with confining deletions to bona fide classified materials cast significant doubt on the validity of the SCI Nondisclosure Agreement under Freedman.

\section{B. Overbreadth and Vagueness}

The overbreadth and vagueness doctrimes ensure that regulations-whether aimed at speech or not-infrimge upon first amendment freedoms only minimally. As the Supreme Court held in $N A A C P v$.

163. Senate NSDD-84 Hearings, supra note 17, at 19 (testimony of Richard K. Willard, Deputy Assistant Attorney General). But see Mitt, supra note 162, at $42-44$ (describing CIA abuses as recent as last year).

164. 718 F.2d 1137 (D.C. Cir. 1983).

165. Id. at 1149-50. But see Mitt, supra note 162, at 42 (describing McGehee's experience with the CIA prior to the litigation); Kilpatrick, Balancing freedom and security, San Jose Mercury, Apr. 3, 1984, at 7B, col. 3 (describing a 1982 incident in which the CIA withheld approval of a manuscript of a novel because of its description of a fictitious computer chip).

Congress is also apparently unconvinced that the government would enforce prepublication review in good faith. Indeed, the House Post Office and Civil Service Committee recommended that H.R. 4681 be passed to prevent implementation of the agreement in part because "[p]republication review will probably be enforced capriciously," House H.R. 4681 REPORT, supra note 67, at 28, and specifically dirccted agaimst critics of government policies, id. at 32 .

166. Senate NSDD-84 Hearings, supra note 17, at 19-20 (testimony of Richard K. Willard, Deputy Assistant Attorney General).

167. See Blasi, supra note 84 , at $80-82$.

168. Id. at 81 .

169. See infra notes 315-19 and accoinpanying text. 
Button, ${ }^{170}$ "Precision of regulation must be the touchstone in an area so closely touching our most precious freedoms."171 Besides precision, the doctrines also seek predictability of government intervention. Still, the tests permit courts to strike down regulations without inhibiting the government's power to regulate in the area. ${ }^{172}$ The presumption underlying these doctrines is that the government "can always find a better and constitutional way if it will keep trying" to draft its regulations more carefully. ${ }^{173}$

\section{Overbreadth}

The overbreadth doctrine specifically addresses questions that arise when the plain language of a legitimate, speech-regulating statute sweeps within its ambit activities that are constitutionally protected. As the doctrine has developed, it can be used in two ways. ${ }^{174}$ First, one can complam along traditional lines that a particular rule, as applied to him, has worked to punislı norinally protected activity. Second, the doctrine can be used to attack regulations that are facially overbroad, even if the conduct the complamant is being punished for would clearly be regulable under a more narrowly drawn statute. This relaxation of the standing rule has been instituted to give the first amendinent additional "breathing space . . . . [T] he possible harn to society in permittimg some unprotected speecls to go unpunished is outweiglied by the possibility that protected speech of others niay be inuted and perceived grievances left to fester because of the possible inhibitory effects of overly broad statutes." 175 In such instances, case-by-case adjudication would be mappropriate because it would not remove the in terrorem effect on conduct technically within first anendment protection. ${ }^{176}$

170. 371 U.S. 415 (1963).

171. Id. at 438.

172. See M. SHAPIRo, supra note 5, at 140-41.

173. Id. at 142 .

174. These have been thoroughly explored in Note, The First Amendment Overbreadth Doctrine, 83 HARv. L. REv. 844 (1970).

175. Broadrick v. Oklahoma, 413 U.S. 601, $611-12$ (1973); see also Dombrowski v. Pfister, 380 U.S. 479 (1965); Thornhill v. Alabama, 310 U.S. 88 (1940); Note, The Void-for-Vagueness Doctrine in the Supreme Court, 109 U. PA. L. REv. 67, 75-76, 80-81, 96-104 (1960).

176. Note, supra note 174, at 853. Professor Bogen sees conditional government benefits such as public employment or professional licenses as one area where overbreadth analysis is "particularly appropriate." First, case-by-case adjudication is not a good idea in this area since the legislature enacted a rule specifically to eliminate the need for case-by-case review. By using the overbreadth doctrine, the court remands the issue to the legislature rather than to the courts. Second, use of overbreadth analysis does not remove the state's ability to regulate in the area since it may redraft its statute more narrowly. This can elinimate potential federalism problems. Bogen, First Amendment Ancillary Doctrines, 37 MD. L. Rev. 679, 706-07 (1978). For a discussion of the overbreadth doctrine generally, see $i d$ at 705-14. 
As Professor Karst points out, ${ }^{177}$ the overbreadth doctrine also serves another function: the estabhshment of specific standards that reduce the possibility of improper selective enforcenent. ${ }^{178}$ When a statute is drawn broadly, it may grant enforcement officials too much discretion to decide when or if to enforce it. ${ }^{179}$

In recent years, the Court has narrowed the overbreadth doctrine, now requiring "substantial overbreadth" before a statute will be held facially invalid. ${ }^{180}$ Standing to make facial attacks has also been narrowed, and courts now examine whether the complamant's conduct was withm the "hard-core" of a statute-conduct that could without question be prohibited constitutionally. ${ }^{181}$ Fmally, facial challenges will not be heard unless a statute is "not readily subject to a narrowing construction." 182 To do otherwise might unnecessarily interfere with a generally proper regulatory program.

Consequently, application of the overbreadth doctrine to invalidate a statute on its face is "manifestly strong inedicine" to be employed by a court "sparingly and only as a last resort."183 The pohicy relegates potential overbreadth challenges to case-by-case determinations-a disfavored result according to soine-because it "holds preferred freedoms in abeyance for an indefinite period and tolerates the intimidation of protected activity caused by a law whose (literal or per1missible) scope is uncertain." 184 Thus, the potential evils of an overbroad statute bear solne similarity to the evils of a prior restraint.

177. Karst, Equality as a Central Principle in the First Amendment, 43 U. CHI. L. REv. 20, 3839 (1975).

178. Professor Karst cites, as an example, a statute that bars demonstrations in public streets. Faced with a post-football game victory rally, police look the other way; yet they enforce the statute when an antiwar protest fills the streets. Id. at 38.

179. The problem can also be seen as one of vagueness. See infra notes 187-88 and accompanying text. For examples of statutes that lrave fallen due to selective enforcement, see Cox v. Lousiana, 379 U.S. 536 (1965); Cantwell v. Connecticut, 310 U.S. 296 (1940); Hague v. Committee for Indus. Org., 307 U.S. 496 (1939). For a current example of invalid selective enforcement, see United States v. Schmucker, 721 F.2d 1046 (6th Cir. 1983) (permitting first amendment challenge to a prosecution for failure to register for the draft where the defendant had made known his intention not to register by writing to President Reagan and where only a handful of similarly situated people, of the estinnated 500,000 others who had violated the statute, were prosecuted). But see Umited States v. Wayte, 710 F.2d 1385 (9th Cir. 1983) (holdimg prosecution for failure to register for the draft under similar circumstances valid as within prosecutorial discretion), cert. granted, 104 S. Ct. 2655 (1984).

180. Broadrick v. Oklahoma, 413 U.S. 601, 615-16 (1973).

181. See generally id. But see Bigelow v. Virginia, 421 U.S. 809, 815-18 (1975) (permitting a facial attack on an overbroad statute that regulated speech rather than conduct).

182. Erznoznik v. Jacksonville, 422 U.S. 205, 216 (1975).

183. Broadrick v. Oklahoma, 413 U.S. 601, 613 (1973); accord Bigelow v. Virginia, 421 U.S. 809,817 (1975).

184. Note, supra note 174 , at 875 . 


\section{Vagueness}

The vagueness doctrine is closely related to the overbreadth doctrine, as it also voids statutes that fail to give the first amendment adequate breathing space. ${ }^{185}$ Despite the considerable overlap between the doctrines, their reaches are somewhat different. While the overbreadth doctrine examines whether the scope of a statute's plain language sweeps in protected conduct, the vagueness doctrine focuses on the language itself for indefiniteness. The traditional test is whether the language is so unclear that "men of cominon intelligence must necessarily guess at its meaning." 186 But beyond the notion that a vague statute does not give a person fair notice that he is acting in a prohibited area, the doctrine also requires legislatures "to set reasonably clear guidelines for law enforcement officials and triers of fact im order to prevent 'arbitrary and discriminatory enforcement.' "187 Offcials must have well-defined standards against which to measure their actions when a regulation infringes individual freedoms such as free speech. $^{188}$

When considering the vagueness of a statute, the Supreme Court im recent years has adopted an approach quite similar to overbreadth analysis. Specifically, the Court will look not just to the plain language of the enactment but also to narrowing court interpretations and regulations promulgated under the statute and in related areas. Thus, in Arnett v. Kennedy, ${ }^{189}$ the Court upheld, over a vagueness attack, the Lloyd-LaFollette Act, ${ }^{190}$ which permits the government to remove or suspend without pay a federal civil servant "for such cause as will promote the efficiency of the service."191 The case involved dismissal of a civil servant who had allegedly inade false and defamatory statements

185. See generally M. SHAPIRO, supra note 5, at 140-42; Note, supra note 175, at 75 ("[T] doctrine of unconstitutional indefiniteness has been used . . . almost invariably for the creation of an insulating buffer zone of added protection at the peripheries of several of the Bill of Rights freedoms.").

186. Broadrick v. Oklahoina, 413 U.S. 601,607 (1973) (quoting Connally v. General Constr. Co., 269 U.S. 385, 391 (1926)).

187. Smith v. Goguen, 415 U.S. 566, 572-73 (1974); see also Cox v. Louisiana, 379 U.S. 536 (1965).

188. This selective enforcenent prohibition is perhaps the largest reason for confusion between overbreadth and vagueness because an overbroad statute is inherently vague. If a statute is patently overbroad, uncertainty arises when "the inan of ordinary intelligence tries to guess not the literal scope but the permissible scope." Note, supra note 174 , at 874 ; see also Cox v. Louisiana, 379 U.S. 536 (1965); Bogen, supra note 176, at 714-26; Note, supra note 175, at 110-16. Selective enforcement can occur when the authorities decide the permissible scope on a case-by-case basis, with extrimsic inatters, such as race or political persuasion, altering the boundary.

189. 416 U.S. 134 (1974).

190. Lloyd-LaFollette Act, ch. 389, §6, 37 Stat. 555 (1912) (current version at 5 U.S.C. $\S \S 7503,7513$ (1982)).

191. Id. 
about a superior. Noting that the statute was not aimed at regulating speech, the Court stated that its language had to be read in light of the "longstanding principles of einployer-einployee relationships" that have been developed over the years and used by the Civil Service Coinmission in interpreting acts of Congress. ${ }^{192}$ Additionally, the Court used the "hard-core" notion seen in overbreadtl cases to deny standing to challenge a statute as unconstitutionally vague if the challenger's conduct was clearly regulable under a nore carefully drawn statute. ${ }^{193}$

When considering the validity of executive acts undertaken to protect national security, courts have moved cautiously, recognizing the "inherent vagueness" of the concept of "national security." 194 Tlius, in holding that domestic wiretapping authorized solely by the executive violated the fourtl amendment guarantee against illegal searclies and seizures, the Supreme Court stated, "The danger to political dissent is acute where the Government attempts to act under so vague a concept as the power to protect "doinestic security." "195 On the other liand, the added specificity of an executive order's provisions saved from a vagueness challenge the government's systein of classifying documents that "reasonably could be expected to cause serious damage to the national security."196

\section{Invalidity of the Prepublication Review Program Under the Overbreadth and Vagueness Doctrines}

\section{a. Overbreadth and Vagueness of the SCI Nondisclosure Agreement}

The SCI Nondisclosure Agreement, coupled with the impleinenting regulations, is facially overbroad. An einployee reading the agreement would see an apparently precise edict-all materials must be submitted for prepublication review if they contain certain types of in-

192. Arnett, 416 U.S. at 160 . Also important to the Court was the fact that the employee's government agency had established a procedure providing counsel for employees with questions about the Act's provisions. Id. A similar procedure was found important in United States Civil Serv. Comm'n v. National Ass'n of Letter Carriers, 413 U.S. 548, 580 (1973). In upholding the Hatch Act restrictions on government employees' involvement in politics over a vagueness attack, the Court noted that under the procedures, "an employee in doubt about the validity of a proposed course of conduct may seek and obtain advice from the Commission and thereby remove any doubt." Id.

193. See Parker v. Levy, 417 U.S. 733, 756 (1974) ("One to whose conduct a statute clearly applies may not successfully challenge it for vagueness."); Arnett, 416 U.S. at 162-63; Colten v. Kentucky, 407 U.S. 104, 111 (1972); see also supra note 181 and accompanying text.

194. Halperin v. Kissinger, 606 F.2d 1192, 1200 (D.C. Cir. 1979), aff d by an equally divided Court, 452 U.S. 713 (1981).

195. United States v. United States Dist. Court, 407 U.S. 297, 314 (1972); see also Zweibon v. Mitchell, 516 F.2d 594, 653-54 (D.C. Cir. 1975) (en banc) (the concept "affecting foreign relations" is vague and subject to abuse), cert. denied, 425 U.S. 944 (1976).

196. McGehee v. Casey, 718 F.2d 1137, $1143-47$ (D.C. Cir. 1983). 
formation. ${ }^{197}$ But unless an employee must submit everything he writes or plans to say for review-plainly mipermissible ${ }^{198}$ - he cannot know whether a particular item is subject to review unless it clearly contains classified information or SCI. The agreeinent, for example, covers "any information concerning intelligence activities, sources or methods." This category could conceivably include every communication that touches on foreign policy, defense policy, or atomic energy.

Even some of the subcategories of SCI-related information, which inust be submitted for review, ${ }^{199}$ may be unconstitutionally vague. The words appear clear enough, but because their scope is plainly broader than what is permissible, people must guess at whether a particular utterance is within the agreement. For example, the phrase "any description of activities that produce or relate to SCI" displays the same vagueness and overbreadth probleins that plagued the antisubversive law that punished "advocacy" of criminal anarchy. ${ }^{200}$ Is it mipermissible for a government agent to describe what SCI is? ${ }^{201}$ Is a person permitted to discuss the general operations of the Defense Department? No person can know, but under the regulations, the employee assumes all risk of error on this judgenent, even if he is not covered by the SCI agreement. ${ }^{202}$

\section{b. Shortcomings in the Regulations}

In addition to the difficulties with the agreement itself, some of the regulations are also unconstitutionally vague. For example, one regu-

197. See supra text accompanying note 42.

198. McGehee v. Casey, 718 F.2d 1137, 1141 (D.C. Cir. 1983) ("The government has no legitimate interest im censoring unclassified materials."); United States v. Marchetti, 466 F.2d 1309, 1313 (4th Cir.) (first amendment bars the government from imposing, "contractually or otherwise," censorship of unclassified materials or information), cert. denied, 409 U.S. 1063 (1972). 42.

199. SCI Nondisclosure Agreement, supra note 34, at \$5(a); see supra text accompanying note

200. See, e.g., Keyishian v. Board of Regents, 385 U.S. 589, 599 (1967). There, the Supreme Court discussed a New York criminal statute that made a person guilty of advocating criminal anarchy if he "publicly displays any book . . . containing or advocating, advising or teaching the doctrine that organized government should be overthrown by force, violence or any unlawful means." Demonstrating the overbreadth, the Court said:

Does the teacher who carries a copy of the Communist Manifesto on a public street thereby advocate criminal anarchy? It is no answer to say that the statute would not be applied in such a case. We cannot gainsay the potential effect of this obscure wording on "those with a conscientious and scrupulous regard for such undertakings." . . The teacher cannot know the extent, if any, to which a "seditious" utterance must transcend mere statement about abstract doctrine, the extent to which it must be imtended to and tend to indoctrinate or imcite to action in furtherance of the defined doctrine. The crucial consideration is that no teacher can know just where the line is drawn . . . .

Id. (citations omitted) (quoting Baggett v. Bullitt, 377 U.S. 360, 374 (1964)). 34.

201. If so, this would explain the unavailability of a succinct definition of SCI. See supra note

202. See supra notes $35,49-50$ and accompanying text. 
lation exempts from the review requirement material consisting "solely of personal views, opinions or judgments" and not containing or implymg any statement of fact. ${ }^{203}$ This regulation is either meaninglessbecause all statements of opinion mvolve some use of facts-or it is unconstitutionally vague. The fact-opinion dichotomy has plagued courts for years in libel cases. ${ }^{204}$ The law is far from clear there, even for experts in the field. The standard is clearly one where " 'Inen of common imtelligence must necessarily guess at its meaning." "205 The next portion of the regulation, no doubt intended as a clarification, does not sinuplify the inquiry:

For example, public speeches or publication of articles on such topics as proposed legislation or foreign policy do not require prepublication review as long as the material does not directly or implicitly constitute a statement of an informational nature that falls within [one of the categories subject to review under the SCI Nondisclosure Agreement]. Of course, im some circumstances the expression of "opinion" may inuply facts and thus be of such a character as to require prior review. ${ }^{206}$

Not only are these sentences illogical and internally inconsistent, but they mcorporate any overbreadth and vagueness problems in the SCI Nondisclosure Agreement itself. ${ }^{207}$ This requirement cannot withstand scrutimy under the vagueness doctrine. The agreement's broad sweep subjects unreviewable material to scrutiny and also punislies others without fair notice. ${ }^{208}$

\section{c. Possibility of Selective Enforcement}

These same defects also permit selective enforcement, a further concern of overbreadtli and vagueness doctrine. Tliough discriminatory prosecution has been a problein in the CIA in the past, with nondisclosure agreements enforced only against critics of the Agency or the government, ${ }^{209}$ enforcement of the CIA agreement today appears far

203. DOJ 2620.8, supra note 40 , at I $5(\mathrm{~h})$.

204: See generally Information Control Corp. v. Genesis One Computer Corp., 611 F.2d 781 (9th Cir. 1980).

205. Broadrick v. Oklahoma, 413 U.S. 601, 607 (1973) (quoting Connally v. General Const. Co., 269 U.S. 385, 391 (1926)).

206. DOJ 2620.8, supra note 40, at If $5(\mathrm{~h})$.

207. See supra notes 197-202 and accompanying text.

208. Under the regulations, if an employee is in doubt about whether a particular item must be submitted for review, the government will clarify the matter in individual cases upon request. See DOJ 2620.8, supra note 40, at I 5(c). Such a provision has been important to the Court in the past in passing on vagueness questions. See supra note 192 and accompanying text. But the availability of a clarifying explanation could not by itself save so vague a set of regulations. This is especially true simce in order to authoritatively clarify individual cases, the government will have to first inspect the material in question. Thus any exemption from the regulations that might exist is a hollow one indeed.

209. See A. Dershowitz, The Best Defense 228, 231-32 (1983); Mitt, supra note 162, at 42- 
more uniform. ${ }^{210}$ But the CIA's selective enforcement history did not result from ambiguities in the CIA agreement. It was purely pohitical. By contrast, the vagueness and overbreadth of the SCI Nondisclosure Agreement facilitate its selective enforcement for improper purposes. If an opimion were favorable to the government, for example, it could be declared to be within the opinion exception. Unfavorable opinions could be said to imply facts and so be subject to review. This need not even be a conscious act by the censor. If an employee's material is critical of the government, it may be quite natural for the reviewer to analyze it more closely and find within the opinion underlying facts that bring the material within the agreement.

\section{d. Overbreadth, Vagueness, and Current Supreme Court Doctrine}

Even with these overbreadth and vagueness difficulties, the agreement and regulations inight well withstand a facial challenge under current Supreme Court doctrine. For example, if the challenger is one who refused to subinit materials that in fact contam SCI or classified material, it is unlikely the Supreme Court would hear him complam. The person would be within the "hard-core" of the review requirement and so lack standing to challenge the scheme. ${ }^{211}$ Similarly, if another person challenged the regulations as apphed to him, the Court could simply invalidate the scheme as apphed, leaving intact the regulatory system for those situations when it was still useful and constitutional. Indeed the Court might well adjudicate all disputes that arise under such an agreement on a case-by-case basis rather than declare the scheine facially invahd, because of the iniportant governmental interest involved. Such an outcome would certainly confirm the fear of those who dislike case-by-case adjudication in first amendment overbreadth cases because of the potential chilling effect the existence of the regulation has on fully protected speech. ${ }^{212}$

44; Committee Report, The Response 10 Snepp v. United States: A Proposal for the 97th Congress, 36 REC. A.B. CITY N.Y. 299, 307 (1981); see also Agee v. CIA, 500 F. Supp. 506, 508-09 (D.D.C. 1980).

Snepp also raised the selective enforcenent issue, but the courts rejected it despite ClA admissions that it had taken no action against at least two authors who had published books about the CIA without the required prepubhication review. See United States v. Snepp, 595 F.2d 926, 932-33 (4th Cir. 1979), rev'd in part and remanded, 444 U.S. 507 (1980) (per curiam).

210. See, e.g., Senate NSDD-84 Hearings, supra note 17, at 144-63 (copies of settlement agreements and court decrees granting CIA damages and imjunctive relief for breach of the preclearance requirement by various former CIA employees, including former C1A Director William Colby); The CIA Turns Tables On IIs Former Master, NEwsweEK, May 30, 1983, at 61 (former CIA Director Stansfield Turner ordered to make numerous changes in the manuscript of his book by CIA censors).

211. See supra notes $180-83,193$ and accompanying text.

212. See supra notes $175-76,184$ and accompanying text. 


\section{The Unconstitutional Conditions Doctrine}

\section{Development of the Doctrine}

While the prepublication review program may be both an invalid prior restraint and unconstitutionally overbroad and vague, it may also be attacked as an unconstitutional condition on employment. As the Supreme Court has noted, '[E]ven though a person has no 'right' to a valuable government benefit . . . [the government] may not deny a benefit to a person on a basis that infringes his constitutionally protected interests-especially, his interest im freedom of speech."213 The government is so constrained despite the fact that it can deny a benefit for any of a number of reasons-or even for no reason whatsoever. ${ }^{214}$

In adoptimg this "unconstitutional conditions" doctrine, the Supreme Court erased a long-standing view expressed by Justice Holmes while he was still on the Massachusetts Supreine Judicial Court. In McAuliffe v. Mayor of New Bedford, ${ }^{215}$ Holmes stated:

The petitioner may have a constitutional right to talk politics, but he has no constitutional right to be a policeman. There are few employments for hire in which the servant does not agree to suspend his constitutional right of free speech, as well as of idleness, by the implied terms of his contract. The servant cannot complain, as lie takes the employment on the terms which are offered him. ${ }^{216}$

In the late 1950 's, the Supreme Court came to view such conditional benefits as "palpable violation[s] of the First Amendment."217 For example, in Speiser v. Randall, ${ }^{218}$ California had denied a tax exemption to an otherwise eligible veteran because of his refusal to sign a loyalty oath. The Court, striking down the condition, held that when the state seeks to limit speech through use of its general taxing program, due process requires that the speech remain "unencumbered until the State comes forward with sufficient proof to justify its inhibition."219

The Speiser rule was extended to the government employment context over the next several years. In Keyishian v. Board of Regents, 220 a case involving dismissal of state university instructors for refusal to sign a loyalty oath, the Supreme Court stated that " the theory that public employment which may be denied altogether nay be subjected

213. Perry v. Sindermann, 408 U.S. 593, 597 (1972).

214. Id; Mt. Healthy City School Dist. Bd. of Educ. v. Doyle, 429 U.S. 274, 283 (1977).

215. 155 Mass. 216,29 N.E. 517 (1892).

216. Id. at 220,29 N.E. at $517-18$.

217. Speiser v. Randall, 357 U.S. 513, 530 (1958) (Black, J., concurring).

218. 357 U.S. 513 (1958).

219. Id. at $528-29$.

220. 385 U.S. 589 (1967). 
to any conditions, regardless of how unreasonable, has been uniformly rejected." "221 Since then, the Court has reiterated the invalidity of conditions on government employment and other benefits that would otherwise violate the recipient's constitutional rights. ${ }^{222}$ "[G]overnments, even in the exercise of their internal operations, do not constitutionally have the complete freedom of action enjoyed by a private employer." 223

Notwithstanding the unconstitutional conditions doctrine, it is clear that the government as an employer can regulate speech to some degree. Moreover, the degree of such permissible regulation is greater than the degree to which the government can regulate speech of the general population. ${ }^{224}$ As the Supreme Court held in Pickering $v$. Board of Education, ${ }^{225}$ "The problem . . . is to arrive at a balance between the interests of the [einployee], as a citizen, in commenting upon matters of public concern and the interest of the State, as an employer, in promoting the efficiency of the public services it performs through its employees."226 This balancing test was further explained in Connick $v$. Myers, ${ }^{227}$ where the Court held that government has wide latitude to regulate employees' on-the-job speech as long as it does not involve a matter of "political, social, or other concern to the community."228 While the Keyishian doctrine retains viability, the Court has inore recently upheld several conditions on government employment where the

221. Id. at 605-06 (quoting Keyishian v. Board of Regents, 345 F.2d 236, 239 (2d Cir. 1965)); cf. Sherbert v. Verner, 374 U.S. 398 (1963) (benefit cannot be denied or conditioned on acts that infringe freedom of religion).

222. See, e.g., Branti v. Finkel, 445 U.S. 507 (1980) (blocking employee dismissal based on his political party affiliation); Elrod v. Burns, 427 U.S. 347 (1976) (same); Pickering v. Board of Educ., 391 U.S. 563 (1968) (blocking school teacher dismissal for writing a letter to a local newspaper criticizing the allocation of school funds).

223. Cafeteria \& Restaurant Workers Union v. McElroy, 367 U.S. 886, 898 (1961). For law review commentary on the unconstitutional conditions doctrine, see, e.g., O'Neil, Unconstitutional Conditions: Welfare Benefits with Strings Attached, 54 CALIF. L. REv. 443 (1966); Van Alstyne, The Demise of the Right-Privilege Distinction in Constitutional Law, 81 HARv. L. REv. 1439 (1968).

224. See Healy v. Jaines, 408 U.S. 169, 203 (1972) (Rehnquist, J., concurring) ("The government as einployer . . . may inpose upon einployees . . reasonable regulations that would be impermissible if imposed by the government upon all citizens.").

225. 391 U.S. 563 (1968).

226. Id. at 568 .

227. 103 S. Ct. 1684 (1983).

228. Id. at 1690. In Connick, a five-to-four Court found that an assistant district attorney's circulation to her fellow staff members of a questioumaire about an office transfer policy and other issues was a matter of internal office policy rather tlian of public concern. The Court accordingly upheld her dismissal.

After Connick, one must distinguish matters of public concern from internal matters. Arguably anything related to the internal operations of the government is a proper matter for public scrntiny. Connick rejects that view, but the decision does recognize that some matters that might be considered internal in the private sector are matters of public concern when related to government. $I d$. at $1690-91$. Where the internal-external lime falls, however, is unclear. 
condition is narrowly drawn and protects a substantial government interest unrelated to suppression of free speech. ${ }^{229}$

As the District of Columbia Circuit has observed, the Supreme Court has expressed a "sensitivity to the special institutional needs of particular governmental services, such as the military and the foreign intelligence services" when analyzing whether the governmental interest protected is "substantial."230 Applying the standard to the CIA prepublication review requirement, and citing Snepp $v$. United States, ${ }^{231}$ the circuit court determined that prepublication review was a permissible condition on CIA employment, at least theoretically. ${ }^{232}$ But as with most of the recent conditional benefit cases, ${ }^{233}$ the vahidity of the condition ultimately turned on how narrowly the condition was drawn. ${ }^{234}$ This necessarily requires an examination of the collateral first amendment doctrine of least drastic means.

\section{Least Drastic Means}

As the unconstitutional conditions doctrine requires, the government may impose restrictions on employees' free speech only if the condition is narrowly drawn. Thus, the prepublication review program may be mvatid as an employment condition if the government could achieve its goals in a less restrictive manner. This "least drastic means" doctrine is closely related to the doctrines of vagueness and overbreadth, ${ }^{235}$ but the overlap is not complete. It recognizes the legitimacy of government regulation in an area, but it requires that the end not "be pursued by means that broadly stifle fundamental personal liberties when the end can be more narrowly achieved."236

229. See Brown v. Glines, 444 U.S. 348, 354-55 (1980) (upholding Air Force regulation prolibiting solicitation of petition signatures on base without authorization); see also United States Civil Serv. Comm'n v. National Ass'n of Letter Carriers, 413 U.S. 548 (1973) (upholding Hatch Act ban on partisan pohticking by government employees); Broadrick v. Oklahoma, 413 U.S. 601 (1973) (upholding similar state ban on political activities by government employees); Cole v. Richardson, 405 U.S. 676 (1972) (upholding narrowly drawn loyalty oath).

Last Term, the Court reiterated that conditions on government benefits that impinge on first amendment rights must be narrowly drawn. See Seattle Times Co. v. Rhinehart, 104 S. Ct. 2199 (1984) (uplrolding protective order imposed as a condition of allowing civil pretrial discovery); $i d$. at 2210 (Brennan, J., concurring).

230. McGehee v. Casey, 718 F.2d 1137, 1142 n.11 (D.C. Cir. 1983).

231. 444 U.S. 507 (1980) (per curiain).

232. McGehee, 718 F.2d at 1142-43.

233. See cases cited supra note 229.

234. McGehee, 718 F.2d at 1143-47.

235. Indeed, one commentator has asserted that the least drastic means doctrine is relatively useless since, among other reasons, it is duplicative of other doctrines that can be used to invalidate speech regulations. Note, Less Drastic Means and the First Amendment, 78 YALE L.J. 464 (1969).

236. Shelton v. Tucker, 364 U.S. 479, 488 (1960) (footnote omitted). For otlier cases applying the doctrine in the first amendment context, see, e.g., Brown v. Glines, 444 U.S. 348, 355 (1980); 
The least drastic means doctrine has been criticized because when the Supreme Court mvokes it, the Justices rarely enunciate any less drastic alternative, possibly because of the Court's general reluctance to issue advisory opimons. ${ }^{237}$ At the same time, the test is recognized as an important aspect of first amendment balancing because, in order to give first amendment values appropriate weight, courts must balance "no more than the state's imterest im the added effectiveness of the chosen means against the imdividual interest in the use of less drastic ones."238 Alternatively, least drastic means can be seen as a restatement of the familiar requirement that tinne, place, and inanner regulations on speech be "reasonable." 239

The least drastic means doctrine requires that regulations be drawn to "restrict speech no more than is reasonably necessary" to protect a substantial government imterest. ${ }^{240}$ It does not force the government to cease regulation in any area that has a negative collateral impact on free speech, though this would clearly be the "least means" m an absolute sense. Indeed, as Brown $v$. Glines ${ }^{241}$ shows, least drastic means does not even inean "not drastic" means. There, the Court upheld an Air Force regulation prohibitimg the solicitation of signatures on a petition without advance clearance from a commanding officer who had total discretion to approve or deny the request. ${ }^{242}$ The doctrine permits use of drastic means if the important governmental purpose can be achieved only in that way.

\section{Validity of the Prepublication Review Program Under the Unconstitutional Conditions Doctrine}

Were the President's proposal to impose lifelong prepublication review on all government employees, it would likely be invalid as an unconstitutional condition on employment. Such a general restriction on the first amendment rights of employees cannot be justified given the Connick limitations on the government's ability to regulate employee speech that relates to matters of public concern. But the Reagan prepublication review proposal im fact is narrower. It would place this

United States v. Robel, 389 U.S. 258, 268 (1967); NAACP v. Alabama, 377 U.S. 288, 307-08 (1964); NAACP v. Button, 371 U.S. 415, 438 (1963).

237. See Note, supra note 235, at 471. But see Regents of the Univ. of Cal. v. Bakke, 438 U.S. 265, 316-18 (1978) (opinion of Powell, J.) (Harvard minority admissions plan described as a permissible alternative to the strict quota system that had been used at the University of California at Davis Medical School and which was struck down by the Court on equal protection grounds).

238. Note, supra note 235 , at 468.

239. See M. Shapiro, supra note 5, at 142.

240. Brown v. Glines, 444 U.S. 348, 355 (1980).

241. 444 U.S. 348 (1980).

242. Id. at $349-50$. 
condition only on persons with access to SCI. ${ }^{243}$ Thus, a different analysis is more appropriate.

Under the rule of Brown v. Glines, ${ }^{244}$ the employment condition at issue first inust protect an important governmental interest unrelated to the suppression of free speech. ${ }^{245}$ The prepublication review program qualifies under this test; protecting national security is certainly an important governmental function. ${ }^{246}$ The second prong of the test requires regulations that "restrict speech no more than is reasonably necessary" to protect the government's interest. ${ }^{247}$

Given this least drastic means requirement, the SCI Nondisclosure Agreement is probably invalid. There are, after all, other ways for the government to accomphish its goals of impressing employees with the importance of preserving secrecy as well as reducing unauthorized classified-information disclosures without such gross infringement on the first amendment. The government could begin by implementing the other recommendations of the Interdepartmental Group, including tightened imternal security programs, plus a system of post-pubhication criminal and administrative sanctions for persons who fail to comply with secrecy regulations. ${ }^{248}$

The regulations also illustrate how the proposed review program violates the least drastic means standard. Some of the provisions are simply unreasonable. For example, the regulations exempt certain types of utterances from the review requirement. Oral statements are

243. However, the requirement may in fact be far broader, since all persons with access to classified information are required to sign a nondisclosure agreement under NSDD-84. This nondisclosure agreement can be seen to impose a de facto review rcquirement on those employees since it imposes civil penalties for disclosure of classified information. See supra notes 35,50 and accompanying text.

244. 444 U.S. 348 (1980).

245. See supra notes $230-34$ and accompanying text.

246. This analysis assumes that the goal of the proposed prepublication review program is indeed the protection of national security. The conclusion of benign intent here is not autoinatic, however. Several commentators have voiced skepticisin, viewing NSDD-84 as but the latest chapter in an established "clear and consisteut pattern of restricting the availability of government information to the pubhc." HoUSE NSDD-84 REPORT, supra note 17, at 22 (additional views of Rep. Glenn Euglish); see also Abrams, The New Effort to Control Information, N.Y. Times, Sept. 25, 1983, $\$ 6$ (Magazime), at 22 ("sweeping policy"). Indeed, in liearings on NSDD-84 before a House subcoinmittee, the Reporters Committee for Freedoin of the Press chronicled 30 specific acts of the Reagan admimistration that it said constituted a "carefully conceived and counprehensive plan to censor virtually all types of government information." House NSDD-84 Hearings, supra note 17 (statement of Jack C. Landau, executive director, Reporters Comm. for Freedom of the Press). The list includes the reduction of funds for the national archives, the denial of visas to controversial foreign speakers, the restriction of the screening of films covering controversial subjects, and the revision of classification procedures to expand the amount of government information that may be classified. Abrams and English also discuss numerous admimistration acts that broadly restrict the flow of information both from the government and through the government.

247. Brown, 444 U.S. at 355; see also supra text accoinpanying note 234.

248. See infra notes 301-14 and accoinpanying text. 
exempt unless there is reason to believe in advance that the statements may contam SCI or other classified information. ${ }^{249}$ An employee reinains liable for violation of the agreement, however, if his statement does include SCI or classified information. ${ }^{250}$ But this provision makes no sense in terms of the government's purported aim-to screen materials for inadvertent releases of classified information. Clearly if the speaker had known the information was classified and would come up in discussion, he should have had it reviewed. Failure to have it cleared ineans it was an intentional disclosure. Similarly, if he had known it was classified but did not know it would come up im conversation, liability should attach since the disclosure would again result from the speaker's intentional act. But if the speaker did not know the material was classified-whether or not he anticipated discussing it in his speech - he would, under the plain language of the regulations, have been under no duty to preclear his speech; yet he would be hable under the same regulation for failure to preclear. Moreover, the only apparent solution to this problem appears to be a bar on all impromptu speaking engageinents by SCI-access employees since an employee can only know what he is planning to say in advance if he speaks from a prepared text. Suclı an outcoine is plainly invalid.

\section{Snepp and Related Cases}

The doctrimes explored above illustrate the predominant first amendment issues raised by a licensing system. But the analysis cannot end there. In Snepp v. United States, ${ }^{251}$ the Supreine Court summarily ${ }^{252}$ upheld a prepublication review program in use at the CIA without addressing the first amendinent issues involved. ${ }^{253}$ The majority saw the case instead as one involving a breach of fiduciary and contractual obhigations. ${ }^{254}$

249. DOJ 2620.8, supra note 40 , at If $5(\mathrm{~g})$.

250. The employee should remain liable under any applicable criminal or administrative provisions if disclosure occurs. However, the only issue here is liability under the agreement.

251. 444 U.S. 507 (1980) (per curiain).

252. The dissenting justices criticized the sumunary nature of the adjudication. Id. at 524-25 (Stevens, J., dissenting). In addition, one commeutator considers Snepp an example of the Burger Court's misuse of summary adjudication to decide novel issues of law. See Rosenberg, Noles from the Underground: A Substantive Analysis of Summary Adjudication by the Burger Court: Part II, 19 Hous. L. Rev. 831, 878-85 (1982).

253. The Court's entire discussion of Snepp's first amendinent claim is relegated to a footnote that essentially states that no first amendinent issue exists. Snepp, 444 U.S. at 509 n.3.

254. Id. at 510,513. This approach has been praised by Professor Easterbrook as a recognition that information is property that deserves protection the way any property deserves protection. Snepp misused the government's property and so inust give up the profits resulting from this misuse. Easterbrook, supra note 89, at 339-53. In an abbreviated analysis, Professor Jeffries appears to support this notion. See Jeffries, supra note 85 , at 435-37 ("The resulting secrecy agreeinent is . . . properly viewed not as a governmental infringement of the liberties of the citizen but 


\section{The Facts}

Frank W. Snepp III was employed by the CIA from 1968 to 1976, and, for much of that period, he served the Agency in Vietnam. Both at the commencement and termination of his employment, Snepp signed security agreements required of all Agency employees in which he promised not to "publish . . . any information or material relating to the Agency, its activities or intelligence activities generally, eitlier during or after the term of [his] employment . . . without specific prior approval by the Agency." 255 As the Suprene Court found, this nondisclosure agreement was an imtegral part of Snepp's concurrent promise "not to disclose any classified information" without authorization. Moreover, Snepp "had pledged not to divulge classified information and not to publislı any information without prepublication clearance."256 During the course of his employment, Snepp was frequently granted access to classified information.

Dissatisfied with the way the CIA had conducted its operations in Vietnam, Snepp resigned in 1976. Shortly thereafter, lie published a book entitled Decent Interval witlout securing CIA approval. The book is a "highly critical account of the United States' withdrawal from Vietnam,"257 containing allegations of CIA malfeasance, nonfeasance, and corruption. Snepp consistently claimed that, thougli the book was based on his experiences in Vietnam, it contained no classified information; moreover, the government never claimed that it did. ${ }^{258}$ Still, the government sued for failure to submit the work for prepublication review, claiming a breach of contractual and fiduciary obligations. The government sought an injunction against future breaches and imposition of a constructive trust over all past and future profits resulting from the breach. ${ }^{259}$

\section{The Lower Court Opinions}

Snepp admitted that lee had not submitted the materials for re-

only as an employer's vindication of the terms of a contract."). The idea that the government owns information the way it owns other property is a sub rosa assumption the Court uses, and this behef is attacked in Whatley, Case Comment: Snepp v. United States, 30 Clev. ST. L. Rev. 247, 284-85 (1981), as inconsistent with a provision in the Copyright Act of 1976 that bars government owuership of a copyright. See 17 U.S.C. § 105 (1982).

255. Snepp v. United States, 444 U.S. 507, 507-08 (1980). Pertinent parts of the two secrecy agreements are set out in United States v. Snepp, 595 F.2d 926, $930 \mathrm{nn} .1,2$ (4th Cir. 1979), rev'd in part and remanded, 444 U.S. 507 (1980) (per curiam). The full text of the agreements may be found in Petition for cert. at 58a-63a (Appendix D), Snepp v. United States, 444 U.S. 507 (1980).

256. Snepp, 444 U.S. at 508 (emphasis in origmal).

257. Snepp, 595 F.2d at 931 .

258. Id. at 935; Snepp, 444 U.S. at 511.

259. Complaint, reprinted in Petition for cert. at 51a, 56a (Appendix D), Snepp v. United States, 444 U.S. 507 (1980). 
view, but he claimed he did not because the materials contained no classified information. To the extent it required review of nonclassified materials, Snepp argued, the secrecy agreenent was invalid under the first amendment.

Rejecting Snepp's various defenses, the district court found that Snepp had "willfully, deliberately and surreptitiously breached his position of trust with the CIA and the secrecy agreement."260 Though the government could not quantify actual damages or causally link Snepp's breach to any particular damage to national security, the court found that Snepp's acts had "impaired [the] CIA's ability to gather and protect intelligence relating to the security of the Umited States of America." 261 The court then fully granted the government's request for an injunction and for imposition of a constructive trust over all royalties Snepp had earned on the book. ${ }^{262}$

The Fourth Circuit similarly rejected Snepp's first amendment claim that the secrecy agreement was imvalid. The court poimted specifically to its previous rulings in United States $v$. Marchetti ${ }^{263}$ and Alfred A. Knopf, Inc. v. Colby, ${ }^{264}$ in which the agreement's validity had been specifically upheld. ${ }^{265}$ However, the court recognized, as it had before in Marchetti and Knopf, that the agreement raises first amendment concerns, primarily along the lines of the Freedman procedural protections of a speedy review confined solely to excision of classified material. ${ }^{266}$

260. United States v. Snepp, 456 F. Supp. 176, 179 (E.D. Va. 1978), aff'd in part, rev'd in part, and remanded, 595 F.2d 926 (4th Cir. 1979), reinstated, 444 U.S. 507 (1980).

261. Id. at 180 .

262. Id. at 182 .

263. 466 F.2d 1309 (4th Cir.), cert. denied, 409 U.S. 1063 (1972). Marchett has been criticized as an example of a case in which the court failed to give first amendnient concerns adequate consideration in light of the particular vuhrerability of government enıployees to suppression and the potential positive aspects of leaking government information. See Comment, Government Information Leaks and the First Amendment, 64 CALIF. L. Rev. 108, 144-45 (1976). The notion that leaks can have an important checking function on the government is the primary thesis of Blasi, supra note 117.

264. 509 F.2d 1362 (4th Cir.), cert. denied, 421 U.S. 992 (1975). Knopf was a later chapter in the same dispute at issue in Marchetti, illustrating the extraordinary pubhication delays that are possible as a result of a prepublication review program. See supra notes 55-58, 139-46 and accompanying text.

Both $M a r c h e t t i$ and Knopf have been criticized for giving inadequate consideration to the difference between secrecy and protection of national security, the latter being the only proper governmental interest. According to this view, the $\mathrm{ClA}$ secrecy agreenent was overbroad and unreasonable and should not have been enforced, due to the tendency of government to overclassify material and the importance of the nation's right to know. See Note, United States v. Marchetti and Alfred A. Knopf, Inc. v. Colby: Secrecy 2; First Amendment 0, 3 HaSt. Const. L.Q. 1073 (1976).

265. Snepp, 595 F.2d at 931.

266. Id. at 931-32, 935. Even after the Supreme Court decision in Snepp, courts contimue to recognize a first ameudinent concern inherent in the CIA secrecy agreement. See McGehee v. Casey, 718 F.2d 1137, $1141 \&$ n.10 (D.C. Cir. 1983). 
The court found, however, that because no classified information had been disclosed, there had been no breach of fiduciary duty. ${ }^{267}$ The duty to submit materials for review was essentially contractual, and the fiduciary duty concerned only disclosure of classified material. Therefore, the court limited the government to contract damages. However, the court ruled that punitive damages were appropriate, and remanded the cause to determine their amount. ${ }^{268}$

\section{Supreme Court Review}

The Supreme Court summarily remstated the district court opinion, based on breach of contract and fiduciary duty theories. On the merits, the Court hardly addressed the first amendment issues. ${ }^{269}$ As for the remedy, the Court said that a tort remedy is inadequate, as is subsequent criminal punishment, because the government is forced to disclose some of the very confidences that the employee promised to protect. $^{270}$ By contrast, the constructive trust remedy is "swift and sure" and is "tailored to deter those who would place sensitive information at risk."271 The Court also rejected the dissent's atteinpt to draw a parallel between Snepp's contractual duty and fiduciary obligations under trade secret law, finding that Snepp's contract with the CIA was made pursuant to the CIA Director's statutory obligation to " "protec $[\mathrm{t}]$ intelligence sources and methods from unauthorized disclosure." "272

Justice Stevens, joined by Justices Brennan and Marshall, dissented, finding no statutory authorization for the secrecy agreement and misuse by the majority of fiduciary obligation doctrime. ${ }^{273}$ Because no classified information was disclosed, the dissenters found a constructive trust was inappropriate. ${ }^{274}$ Moreover, the dissenters did not

267. Snepp, 595 F.2d at $935-36$ \& n.9.

268. Id. at 936-38. Analyzing the remedial aspects of the Fourth Circuit's opinion, one commentator argues that there is no good reason why the first amenduneut can block finding a breach of fiduciary obligation but not a breach of contract. He therefore argues that Snepp did breach a fiduciary obligation and that the constructive trust is the more appropriate remedy. See Commeut, Enforcing the CIA's Secrecy Agreement Through Postpublication Civil Action: United States v. Snepp, 32 STAN. L. Rev. 409 (1980). Published just before the Supreme Court's decision in Snepp, the Comment argues that prepublication review, while in effect a prior restramt, "involves little more than a 30-day opportunity for the CIA to examine a proposed publication." Id. at 418 . This must be distimguished from actual censorship, the author argues. Moreover, a postpublication sanction comes too late to "fulfill prior review's goal of preventing specific disclosures." Id. For a discussion of these issues, see supra notes 112-22 and accompanying text.

269. See supra note 253 and accompanying text.

270. Snepp, 444 U.S. at 514-15.

271. Id. at 515 .

272. Id. at $514 \mathrm{n} .9$ (citing National Security Act of 1947, 50 U.S.C. $\$ 403$ (d)(3) (1976)).

273. Snepp, 444 U.S. at 516-26 (Stevens, J., dissentimg).

274. Id. at 521 (Stevens, J., dissenting). 
agree that prior cases that had sustained some regulations of federal employees that otherwise would have been voided under the first amendment implied approval of a preclearance requirement. ${ }^{275}$

\section{Commentary on Snepp}

The extensive acadeimic commentary on Snepp has been generally negative, with critics characterizing the decision as everything from a misinterpretation of the law of fiduciary obligations, ${ }^{276}$ to a Supreme Court attempt to rewrite first ainendment prior restraint doctrine, ${ }^{277}$ to an overreaction to The Brethren. ${ }^{278}$ Most of these articles favor some sort of postpublication criminal sanction in lieu of prepublication review.

Two articles supporting Snepp deserve special comment. Professor Easterbrook hailed the decision as a recogmition that information is property deserving protection like any other. ${ }^{279}$ Despite the Copyright Act's specific prohibition on government ownership of copyrights, ${ }^{280}$ Professor Jeffries builds on the Easterbrook analysis, justifying the CIA secrecy agreement by moving the frame of reference back to the time when Snepp first souglit employment. According to Professor Jeffries, if the analysis begins tliere, when Snepp has no mformation "but wants to get it,"281 the issue becomes not censorship through a typical prior restraint, but access to information. The government is not attemptimg to restraim Snepp's publication but rather to condition access to its imformation. ${ }^{282}$ Thus, he argues that since Snepp had no right to demand access to secrets, his only access is on terms bargained for in the employment contract.

However, Jeffries' analysis relies on a right-benefit distimction long

275. Id. at 520 \& n.10 (Stevens, J., dissenting).

276. See, e.g., Whatley, supra note 254; Committee Report, supra note 209, at 305-12.

277. See, e.g., Anawalt, A Critical Appraisal of Snepp v. United States: Are There Alternatives to Government Censorship?, 21 SANTA ClaRA L. Rev. 697 (1981); Franck \& Eisen, Balancing National Security and Free Speech, 14 N.Y.U. J. INT'L L. \& Pol. 339 (1982); Medow, supra note 123; Comment, Snepp v. United States: The CIA Secrecy Agreement and the First Amendment, 81 COLUM. L. REv. 662 (1981).

278. See A. Dershowitz, supra note 209, at 230; Whatley, supra note 254, at 247-48.

279. Easterbrook, supra note 89, at 344-45.

280. See Copyright Act of 1976, 17 U.S.C. $\S 105$ (1982), replacing a similar provision in Copyright Act of 1909, 17 U.S.C. \& 8 (1970); see also Letter of Rep. Robert W. Kastenineier, Chairman, Subcomm. on Courts, Civil Liberties and the Adininstration of Justice of the House Comm. on the Judiciary, to Jack C. Landau, executive director, Reporters Comm. for Freedom of the Press (Oct. 25,1978 ) (explaming the Congressman's view that the Copyright Act provision should be dispositive of the Snepp case), reprinted in Amicus Curiae Brief (Reporters Comm. for Freedom of the Press), at i-iv (Appendix A), Snepp v. United States, 444 U.S. 507 (1980).

281. Jeffries, supra note 85 , at 436 (footnote omitted).

282. Id. 
ago rejected by the Supreme Court. ${ }^{283}$ In fact, the view presupposes that Snepp's purpose in getting his government job was to acquire access to government secrets, only later to reveal them publicly. ${ }^{284} \mathrm{But}$ the access to secrets, as Jeffries notes, was necessary for Snepp to perform his employment duties, and it was only after perceived inalfeasance and corruption in government that Snepp felt compelled to expose anything. And, of course, no classified information was in fact revealed in the book.

Perhaps in the private sector, access to information can be inore strictly conditioned, but in the public sector, the analysis cannot be so automatic. There are circumstances in which information access can and should be restricted. But circumstances also exist, especially in the public sector, in which disclosure can perform a very important public service. ${ }^{285}$ A per se rule ${ }^{286}$ either way-permitting full use of information or permitting completely conditional access-is inappropriate. Rather, the prepubhcation review should be subjected to a routine conditional benefit analysis. ${ }^{287}$

\section{Validity of the SCI Agreement Under Snepp}

The preclearance scheme's difficulties under first amendment doctrime assume that the Supreme Court will acknowledge the first amendment concerns involved when it analyzes the problem. ${ }^{288}$ After Snepp, such an assumption inay be unwarranted. The Court might see the entire matter as merely an issue of contract and trust law; and any unenforceability of its provisions would derive froin contract law principles. However, Snepp may be distinguishable.

It is possible that the Snepp Court, cspecially in light of its summary disposal of the matter, saw the case as restricted to its specific

283. See supra notes $213-23$ and accompanying text.

284. If this assumption is correct, cases like Snepp would never involve inadvertent disclosure of classified information. Rather they would be cases of intentional disclosure. The absence of any scienter requirement was the primary basis for Professor Medow's objection to Snepp. See Medow, supra note 123. Moreover, since prepublication review can only be directed at inadvertent disclosures, Jeffries' view argues against enforceability of the prepublication review provision of NSDD-84. See supra notes 127-32 and accompanying text.

285. See Blasi, supra note 117 , passim.

286. It is not clear that Professor Jeffries is advocating such a radical result. His analysis of the situation is abbreviated and is used to illustrate a different point. However, the extrapolation of his analysis indicates the complexity of the problen.

287. See supra notes $213-50$ and accoinpanying text.

288. If the Court excluded the first amendment from the calculus, nothing-except possibly the unconstitutional conditions doctrine, see supra notes 213-34 and accompanying text-would logically prevent the government from extending prepublication review to all government enployees and to all categories of materials. Even use of the unconstitutional conditions doctrine might be foreclosed since protection against potential unauthorized disclosures could well be seen as a "compelling governmental interest." 
facts-a nondisclosure agreement with the CIA. ${ }^{289}$ The sheer magnitude of the decision otherwise seems improbable. If Snepp is not restricted by the uniqueness of the CIA and the NSA, then apparently nothing would prevent the federal government from imposing clearance requirements on all government enployees. ${ }^{290}$ States might impose similar conditions, as might private employers.

But such a limitation of Snepp is appropriate for several reasons. First, the Court's opinion rejects an analogy to trade secret law as having "no bearing" on a contract nnade pursuant to a congressional directive. ${ }^{291}$ Specifically, the Court cited 50 U.S.C. $\S 403$ (d)(3), which states that the CIA Director shall be responsible "for protecting intelligence sources and nethods from unauthorized disclosure."292 Though the statute is not a specific authorization for prepublication review, its mandate is unique. There is no similar authorization for any other agency.

In addition, a number of other provisions indicate a congressional perception that the CIA and the NSA are special cases. For example, CIA appropriations are secret. ${ }^{293}$ The names, salaries, and numbers of CIA and NSA employees are secret. ${ }^{294}$ A merit pay system totally outside the civil service system operates in the NSA in order to induce the nation's top minds to work on supersecret research in cryptology. ${ }^{295}$ Both agencies are subject to the jurisdiction of secret congressional oversight committees in both houses, ${ }^{296}$ and the proceedings of those committees are designed to protect agamst unauthorized disclosures. ${ }^{297}$ Indeed, H.R. 4681, which would prohibit prepublication review and polygrapli use directed against government einployees, specifically exempts the NSA and the CIA from its provisions. ${ }^{298}$

289. The decision might also apply to the NSA, which is quite like the CIA in many respects. See infra notes 291-98 and accompanying text.

290. See supra note 288.

291. Snepp v. United States, 444 U.S. 507, 514 n.9 (1980) (per curiam).

292. Id. (citing National Security Act of 1947, 50 U.S.C. $\$ 403(\mathrm{~d})(3)$ (1976)).

293. 50 U.S.C. $\$ 403 j$ (1976).

294. 50 U.S.C. $\$ 402$ app., Pub. L. $86-36 \S 6(a)$ (1976 \& Supp. V 1981) (NSA); 50 U.S.C. $\S 403 \mathrm{~g}$ (1976 \& Supp. V 1981) (CIA). Both sections specifically exempt the agencies from provisions requiring public disclosure of this information from all other government agencies.

295. 50 U.S.C. $\$ 402$ app., $\$ 12($ b) (Supp. V 1981).

296. 50 U.S.C. $\$ 413$ (Supp. V 1981).

297. 50 U.S.C. $\$ 413$ (d) (Supp. V 1981).

298. H.R. 4681, 98th Cong., 2d Sess. $\$ 2$ (1984) (proposing the addition of a new 5 U.S.C. $\$ 7365)$. In its report recommending passage of H.R. 4681 , the House Post Office and Civil Service Committee gave several reasons why the CIA and the NSA should be exempt from the bill's prohibition on prepublication review and polygraph testing of government einployees. House H.R. 4681 REPORT, supra note 67, at 49-50. First, both agencies are subject to congressional scrutiny through the Permanent Select Committee on Intelligence and other committees. Despite the House Committee's concern about the programs even in these two agencies, the "vigilant oversight" of the CIA and the NSA by these committees reduces the likelihood of abuse through their 
Though not conclusive, these provisions indicate a congressional intent to treat the NSA and the CIA differently from other agencies and departments of the government. This alone would justify limiting Snepp to the CIA and NSA context.

On the other hand, Congress has indicated its intent "to provide a comprehensive program for the future security of the United States [and] to provide for the establishment of integrated policies and procedures for the departments, agencies, and functions of the Government relating to national security."299 Though it does not explicitly so provide, this is the provision under which the President has established a classification system. The statute might be broad enough to permit a government-wide prepublication review requirement. If so, there appears to be little to limit Snepp, and the idea of prepublication review could be sustained under Snepp, subject to the restrictions imposed on such a proposal by the Freedman, overbreadth, and vagueness doctrines. ${ }^{300}$

\section{III \\ Alternatives to the Prepublication Review Program}

If the Supreme Court does not distinguish Snepp and thereby permits wider application of prepublication review, there are still several alternatives to lifelong censorship that could be impleinented to tighten internal security without such a negative impact on the first amendment.

\section{A. Less Drastic Means}

Obviously, the least drastic alternative is to do nothing - an alternative appropriate only if there is no real problem with inadvertent disclosures. For those who believe a problein exists, however, there are several means available that are less severe than prepublication review.

prepublication review systems. Additionally, the Committee found that persons entering the CIA or the NSA know they are entering a "highly secret world where their private lives will be altered in serions ways." Moreover, the security requirements are imposed uniformly on all employees im the agencies, not just on certain persons. Id. at 50 . Because these conditions do not apply in other agencies, the Committee specifically declined requests to grant further exemptions from the prohibitions contained in H.R. 4681. Id.

299. 50 U.S.C. $\$ 401$ (1976 \& Supp. V 1981).

300. Various policy considerations concerning the prepublication review program point toward its withdrawal. These have been cogently discussed elsewhere. See Senate NSDD-84 Hearings, supra note 17; House NSDD-84 Hearings, supra note 17; HOUSE NSDD-84 REPORT, supra note 17; House H.R. 4681 RePORT, supra note 67, at 26-30. 


\section{Tightened Security Programs}

First, the executive branch can pay more "careful attention" to the "fundamental elements of a sound security program," a primary recommendation of the President's 1982 Interdepartmental Group on Unauthorized Disclosures of Classified Information. ${ }^{301}$ The Report specifically recommended three "obvious" measures:

- Security clearances should be given only to individuals who have been determined to be trustworthy on the basis of adequate background information.

-National security information should be clearly identified with the proper classification and stored in a physically secure manner.

-Access to classified information should be given only to persons with the proper clearances and requisite "need to know."302

Additionally, the Report suggested security education programs for senior officials and better controls on copying and circulation of classified documents. ${ }^{303}$

That these recommendations were made at all indicates sorne haphazard handling of top-secret information. Under these circumstances, it is inappropriate to impose prepublication review on employees in response to the government's past failure to protect the nation's secrets. The Report's recommendations state that security program violations are "often inost common at the highest levels of government." 304 The Report leaves one with a tarnished view of government security practices. ${ }^{305}$

Indeed, failure to utilize these fundamental elements of a security prograin inay well contribute to the overbreadth and vagueness problems inherent in the SCI Nondisclosure Agreement. It is difficult for a high-ranking official to differentiate between imformation that "he knows based on access to sensitive information and that he knows

301. INTERDEPARTMENTAL GROUP REPORT, supra note 3, at D1; see also supra notes 24-29 and accoinpanying text.

302. INTERDEPARTMENTAL GROUP REPORT, supra note 3, at D1.

303. Id. at $\mathrm{D} 2-\mathrm{D} 3$.

304. Id. at D1. Indeed, soine commentators suggest that leaks are the frequent result of atteinpts by high-ranking officials to inanipulate public opinion or of failure of the government's own lax security procedures. See, e.g., Franck \& Eisen, supra note 277, at 353-56; see also A. HAIG, supra note 18, at 16-19. These charges of intentional manipulative leaks from high-ranking officials also cast suspicion on the benign justifications of the NSDD-84 security program.

305. The Interdepartmental Group Report states that adherence to basic security principles will not stop the deliberate leaker. INTERDEPARTMENTAL GrouP REPORT, supra note 3, at D1. Thus, its recommendations are directed at the same group as prepublication review-those who inadvertently disclose information. Further, the Report underestimates the ability of tightened security ineasures to prevent deliberate leaks: a person who intends to leak information will in fact be unable to leak it if he has no access to it. Therefore, tightening basic security practices can positively affect the problems of both inadvertent and intentional disclosures. 
based on everything else."306 This problem is only exacerbated when the official has access to secret material that is not so marked or that is stored $\mathrm{m}$ an unsecured manner. At a minimum, the government should restore adherence to basic security principles and show them to be ineffective before imposing lifelong censorship on its employees.

\section{Post-Publication Criminal Sanctions}

Prepublication review may also be unnecessary if improved criminal sanctions are available. The Interdepartmental Group Report noted a gap that leaves certam types of disclosures outside the criminal law. As a result, it recommended enactment of a criminal provision that would simply pumsh all nnauthorized disclosures of classified information. ${ }^{307}$

This alternative to prepublication review is preferable for several reasons. First, it is in every sense a subsequent punishinent ratlier than a prior restraint. Second, it is narrowly confined so that a person could be punished only for actual disclosure of classified inforination, ratler than for mere failure to submit material for review-even if those materials are based on public information. Finally, the provision would clearly place the burden of proof and the burden of going forward on the government rather than on the employee, reducing the likelihood of government harassinent of persons witl unpopular views. In addition, criminalizing unauthorized disclosure has received wide support from those in the security field and civil libertarians. ${ }^{308}$

An interesting variation on the subsequent criminal pumishment proposals was subnitted to Congress in 1981 by the Association of the Bar of the City of New York. Along with a criminal provision, ${ }^{309}$ the association's Committee on Federal Legislation proffered a safe liarbor provision whereby a government employee could voluntarily submit a manuscript for review by the government. ${ }^{310}$ While the author would be under no obligation to accept any government-suggested clianges, acceptance of government recommendations provide the author immunity from criminal and civil sanctions, even if any classified naterial

306. This is one reason the American Civil Liberties Union opposes the SCI prepublication review program. See Press \& Camper, Keeping the Cats in the Bag, NEwSWEEK, Apr. 18, 1983, at 92.

307. INTERDEPARTMENTAL Group REPoRT, supra note 3, at C14-C16.

308. See Committee Report, supra note 209, at 313. Before the Senate hearings on NSDD-84, former CIA Director Wiiliam Colby, while supporting the directive generally, also statcd "I do believe that we are never going to solve this problem [of unauthorized disclosures of sensitive materials] unless we frankly ... establish as a national policy that unauthorized disclosure is a criminal act." Senate NSDD-84 Hearings, supra note 17, at 50 (statement of William E. Colby, former CIA Director).

309. See Committee Report, supra note 209, at 312-14.

310. Id. at 314-15. 
were inadvertently disclosed in the publication. ${ }^{311}$

While this proposal has merit, it suffers from some of the saine difficulties that concern Professor Blasi generally about licensing systems. ${ }^{312}$ It gives the government the opportunity to convimce speakers to alter their expression im order to conform to government preferences, even if there is nothing legally wrong with the proposed expression. And this mcrenuentally shifts the balance toward government control of the speech. Even though the author is under no legal obhgation to accept government recommendations, he may do so simply to avoid what may be a most unpleasant experience later. This danger is reduced by the shifting of burdens inherent in the criminal process. But the safe harbor procedure could also lead to other prior restraimt attempts. For example, having seen a inanuscript, the government imiglit attempt to block its publication through injunction, raismg agam all of the difficulties witl prior restraints. Despite these problems, the safe harbor provision is an alternative to straight prepublication review that deserves consideration.

Neither the Interdepartmental Group's recommended criminal statute nor any variation on it was ever presented to Congress, ${ }^{313}$ probably because of the acknowledged problens with criminal prosecutions in the national security context. ${ }^{314}$ Some of these difficulties, however, are less severe if the government only needs to prove unauthorized disclosure of classified information. For example, unlike a prosecution for treason or espionage, the government in a disclosure case may not have to reveal the importance of the disclosure or prove actual harm to the nation.

\section{Administrative Sanctions for Employees}

Moreover, criminal prosecution may not be necessary in the case of current employees. Many existing sanctions permit the government

\section{Id.}

312. See Blasi, supra note 84 , at $80-82$.

313. In response to a question about the use of general criminal sanctions, Richard Willard told the Senate Committee on Governmental Affairs:

Nearly all unauthorized disclosures of classified information potentially violate one or more existing criminal statutes. Although a new criminal statute could be useful in clarifying ambiguities in existing law, it is unlikely that criminal prosecution would ever by itself be a satisfactory response to most unauthorized disclosures. We beheve that a realistic prospect of administrative sanctions can effectively deter most unauthorized disclosures. Of course, criminal prosecution can and will be considercd where circumstances warrant.

Senate NSDD-84 Hearings, supra note 17, at 25 (responses of Richard K. Willard, Deputy Assistant Attorney General, to written questions from the Committee). While the Committee did not pursue the inatter further, criminal prosecutions combined with tightened security procedurcs may be useful alternatives.

314. See supra notes 20-23 and accompanying text. 
to revoke security clearances or discharge employees for breaches of security. With appropriate notice of its intent to enforce security rules more stringently, the government could impose these sanctions before disclosures occur-the most appropriate time to take action from the government's standpoint. For example, failure to record properly movements of classified documents or failure to store thein properly could be grounds for downgrading or revoking security clearances. Such enforcement would put employees on notice that security is a serious matter. At the same time, breaches would be dealt with more accurately by pumshing only the offender. Under a prepublication review scheme, the entire nation is punished.

\section{B. Prior Restraint and the Freedman Standard}

If the government is determined to institute prepublication review despite the alternatives available, it can still adjust the program to reduce the adverse impact on the first amendment. Assuming that a court would find the first amendment infringement justifiable because of the substantial government interest, the program inust still meet the procedural requirements of Freedman v. Maryland. ${ }^{315}$

First, the delay inherent in prepublication review must be shortened. Agencies must guarantee expedited review whenever there is time value in a manuscript. Even with routime reviews, the process is too long. Revising the time limits so that the government inust process manuscripts in thirty days (imstead of thirty working days) and appeals in fifteen days (instead of fifteen working days) would help, though the move may not be sufficient. And there is no justifiable reason why the government needs six weeks to imstitute injunctive proceedimgs. One week should be sufficient. Finally, some guarantee of expedited judicial review is needed. ${ }^{316}$ While the time limits suggested here are not necessarily sufficient to meet the Freedman standard, they are a step in the right direction.

These shorter time limits should be coupled with a provision placing the burden for failure to review within the deadline on the government. In other words, if the government fails to respond to the employee within the allotted time, the employee may proceed to pubhish his material with impunity. A contrary rule would leave the government with no mcentive to act quickly and would likely render prepublication review as inefficient as FOIA request processing ${ }^{317}$ within a short time.

315. 380 U.S. 51 (1965).

316. The guarantee of expedited judicial review could be similar to that provided in the Freedom of Information Act. See 5 U.S.C. \& 552(a)(4)(D) (1982).

317. See supra notes $142-46$ and accompanying text. 
Under the other Freedman requirements, which help ensure that only bona fide classified material is deleted, three adjustments to the prepublication review program would be beneficial. First, the SCI Nondisclosure Agreement should be altered to impose on the government the burden of seeking an mjunction if an employee does not agree with a government censorship order. Second, Congress could amend the Civil Rights Attorney's Fees Awards $\mathrm{Act}^{318}$ to permit employees who prevail to recover the full cost of cliallenging the government's attempt to censor them. This second suggestion would go far toward solving the problein, without even shifting the litigation burden to the government. Finally, the review system should be subject to congressional oversight. By requiring each agency to report periodically to a congressional oversight committee the number of items submitted, the speed with which they were reviewed, and the number and nature of the deletions ordered, Congress could nonitor whether information crucial to an intelligent debate on national political issues was being withheld. ${ }^{319}$ If it appeared either that such deletions were occurring or that the review process was unnecessary because einployees were abiding by their nondisclosure duty, Congress could act to limit or elininate the prepublication review requireinent.

Combined with a significant reduction in the time required to process materials subnnitted for review, implementation of these recoinmendations could ameliorate the Freedman problems that exist in the origimal SCI Nondisclosure Agreement. Such modifications could help assure the public that any deletions are restricted to bona fide classified material.

\section{Overbreadth and Vagueness}

While compliance with Freedman will cure some of the vagueness difficulties that exist in the proposed SCI agreement, sonie complex problems of overbreadth and vagueness reinain. It may be impossible . to cure the inherent overbreadth and still have a neaningful prepublication review prograin. The ambiguous and broad provisions of the agreeinent are those that expand the inaterials subject to review beyond mere SCI and classified information. ${ }^{320}$ But removal of these other categories would leave "those materials . . . which contain or purport to contain ... SCI . . . or any classified information fronı intelligence

318. Civil Rights Attorney's Fees Awards Act of 1976, 42 U.S.C. $§ 1988$ (1982).

319. The reporting requirement could be inodeled after the Privacy Protection Act of 1980, 42 U.S.C. $\$ 2000 a a-11(b)$ (1982) (requiring an annual report to Congress on warrant-based searches of third-party nonsuspects by federal agents).

320. See supra notes 197-202 and accompanying text. 
reports or estimates" subject to review. ${ }^{321}$ Employees would remain obligated to disclose only those materials that contam information they are not allowed to disclose anyway. Such a modification would essentially destroy the function of the review program.

However, paragraph 5(c) of the agreement, as currently worded, ${ }^{322}$ is so broad that it could conceivably imclude every government-related utterance of a Defense or State Department employee. At a minimum, it should be deleted from the agreement. The regulations on oral statements and opinions are similarly flawed. ${ }^{323}$ Yet the answer to the overbreadth and vagueness problems cannot be siniple replacement of all of the vague provisions witl a blanket provision requiring review of all employee utterances. Such a requirement would be nnworkable and unconstitutional. These problems inherent in the prepublication review program strongly favor the imposition of post-publication sanctions and tiglitened imternal security over prepublication review.

\section{CONCLUSION}

The legal issues surrounding the imposition of lifelong prepublication review are complex. While analysis of the first amendment issues indicates the general unenforceability of the Reagan administration proposal under NSDD-84, that conclusion is undermined by the contract and trust law analysis employed by the Supreme Court in Snepp. While Snepp can conceivably be confined to its particular facts, there is an easier avenue to a constitutional program. Some of the first amendment difficulties witl the prepublication review program can be ameliorated througl adjustments in the SCI Nondisclosure Agreement and its regulations. Without sucl clianges, the legal status of the prepublication review requirement will remain unclear.

Yet there are numerous policy reasons why prepublication review is an ill-advised overreaction to wliat may well be an insigmificant problem. ${ }^{324}$ Sucl a signiflcant change in the federal government's employer-employee relationship should not be instituted by executive order, especially when its ramifications are so great and when its implementation represents sucl a departure from the American ideal of limited government and maximum individual freedom.

Rather, this is a classic area where Congress should express its

321. SCI Nondisclosure Agreement, supra note 34, at If 5 (deleting clause 5(c) and the second two phrases of clause 5(a), described above as overbroad and vague).

322. See supra text accompanying note 42 .

323. See supra notes 203-09, 249-50 and accompanying text.

324. These policy considerations have been addressed by several persons testifying before the Congress. See Senate NSDD-84 Hearings, supra note 17; House NSDD-84 Hearings, supra note 17; HouSE NSDD-84 REPORT, supra note 17; HOUSE H.R. 4681 REPORT, supra note 67, at 26-33; see also Blasi, supra note 84 , at $78-85$. 
views on the matter. ${ }^{325}$ Indications are that the administration's proposal directly conflicts with congressional intent. Given the legal uncertainties, therefore, Congress should settle the matter by prompt passage of H.R. 4681. This should be coupled with an administration effort to tighten security through the conventional means recommended in the Interdepartmental Group Report. ${ }^{326}$ At least until these minimal actions have proven inadequate to correct the inadvertent disclosure problem-and until the government can, through concrete figures, demonstrate that a problem actually exists-a prepublication review program is inappropriate.

Michael L. Charlson*

325. In the Pentagon Papers Case, 403 U.S. 713 (1971), the Supreme Court was unwilling to uphold a prior restraint on publication of stolen, classified government documents absent specific Congressional authority. See supra notes 93-99 and accompanying text.

326. See supra notes $26,301-04$ and accompanying text.

* B.S., M.S. 1981, Stanford University; third-year student, Boalt Hall School of Law, University of California, Berkeley. 